\title{
Cave deposits and sedimentary processes in Cova des Pas de Vallgornera (Mallorca, Western Mediterranean)
}

\author{
Joan J. Fornós ${ }^{1 *}$, Joaquín Ginés ${ }^{2}$, Francesc Gràcia ${ }^{1,3}$, Antoni Merino ${ }^{4}$, \\ Lluís Gómez-Pujol ${ }^{1,5}$, and Pere Bover ${ }^{6,7}$ \\ ${ }^{1}$ Departament de Ciències de la Terra, Universitat de les Illes Balears, Ctra. Valldemossa km 7.5, 07122 Palma, Illes Balears \\ ${ }^{2}$ Federació Balear d'Espeleologia, Palma, Illes Balears \\ ${ }^{3}$ Grup Nord de Mallorca. FBE \\ ${ }^{4}$ Grup Espeleològic de Llubí, FBE, Illes Balears \\ ${ }^{5}$ SOCIB, Balearic Islands Coastal Observing and Forecasting System. ParcBit, Ctra. de Valldemossa km 7,4 07122 Palma (Illes Balears) \\ ${ }^{6}$ Department of Biodiversity and Conservation, Institut Mediterrani d'Estudis Avançats (IMEDEA, CSIC-UIB), Cr. Miquel Marquès 21, 07190 Esporles, \\ Illes Balears \\ ${ }^{7}$ Research Associate, Mammalogy Department/Division of Vertebrate Zoology, American Museum of Natural History, New York, USA
}

Abstract: The Cova des Pas de Vallgornera is an important and protected coastal cave, located in the southern part of the island of Mallorca, that outstands due to its length and the complex processes involved in its speleogenesis. Although sediments are not the main topic of interest, their presence as well as their paleontological contents are valuable evidence for paleoclimatic and chronological reconstructions of the cave morphogenesis. The sedimentary infilling is characterized by a scarce presence of clastic sedimentation, mainly composed of silts and clays, which can only be found at some minor passages in the innermost parts of the cave. It corresponds to a clayey sedimentation mainly derived from the soil infiltration that can be found mixed with carbonate particles detached from the cave walls. A particularly different situation occurs in the northernmost end of the cave where an important sequence of silty sands are present, hosting a very rich paleontological deposit. The objective of this paper is to describe the detrital deposits present in the cave by means of the integration of sedimentological, chemical, and mineralogical data, which will aim to provide a better understanding of the processes that have occurred during the system's speleogenetic evolution.

Keywords: $\quad$ cave detrital sediments; coastal karst; mixing zone; Mn-Fe-rich deposits; Mallorca

Received 27 November 2013; Revised 6 May 2014; Accepted 8 May 2014

Citation: Fornós J.J., Ginés J., Gràcia F., Merino A., Gómez-Pujol L. and Bover P., 2014. Cave deposits and sedimentary processes in Cova des Pas de Vallgornera (Mallorca, Western Mediterranean). International Journal of Speleology, 43 (2), 159-174. Tampa, FL (USA) ISSN 0392-6672 http://dx.doi.org/10.5038/1827-806X.43.2.5

\section{INTRODUCTION}

The Mallorcan coastal landscapes, especially those related with the Upper Miocene carbonates that crop out in the south and southeast parts of the island, are characterized by the frequent existence of littoral karst caves (Ginés \& Ginés, 2011). The presence of sediments in these cave environments has been highlighted in the last years by several papers including those describing recently discovered caves with important underwater extensions (Gràcia et al., 2003, 2005, 2006, 2007, among others), those discussing the speleogenetic processes (Ginés \& Ginés, 2007; Ginés et al., 2009a) and those characterizing the different types of sediments and processes that are present in these littoral areas (Fornós et al., 2009b, 2010).
In the above mentioned papers different types of sediments and genetic processes have been described as being the dominant mechanisms in producing the allochthonous in fillings that were carried into the caves mainly through surface entrances. The most frequent types are reddish-brown fine sediments mostly transported into the cave by surface runoff as in the case of Cova des Coll or Cova Genovesa (Gràcia et al., 2003, 2005), or by eolian processes as in the case of Cova de s'Ònix (Ginés et al., 2007), Cova de sa Font (Egozcue, 1971), Cova de sa Bassa Blanca (Ginés \& Ginés, 1974), among others, or mixed eolian and runoff deposits as is the case of Galeria del Tragus in Cova des Pas de Vallgornera (Fornós et al., 2010). Autogenic processes have also been suggested for Cova de sa Gleda (Gràcia et al., 2007) and in the PirataPont-Piqueta system (Gràcia et al., 2006; Fornós et 
al., 2009b). In these cases granular disintegration due to incongruent corrosion of the calcarenite walls in the mixing zone, or the accumulation of calcite rafts at the bottom of pools, cause an abundant sediment production (Reams, 1968).

All these articles make new contributions to the growing interest demonstrated during the last years in the study of cave sediments among geoscientists (Sasowsky \& Mylroie, 2004; White, 2007; Šroubek et al., 2007; van Hengstum et al., 2010; Martini, 2011; Krajcarz et al., 2013; Springer et al., 2014; among others), and the role of sediments in speleogenesis (Farrant \& Smart, 2011). Related to coastal settings, where sea level oscillation and paleoclimatic and hydrologic implications are object of special interest (van Hengstum et al., 2010, 2011), different areas have been considered: the Balearic Islands (Fornós et al., 2009b), Yucatan Peninsula (Gabriel et al., 2009; van Hengstum et al., 2010), Belize (Polk et al., 2007), Florida (Polk et al., 2013), Bahamas (Kovacs et al., 2013), or Bermuda (Thomas et al., 1991; Hearty et al., 2004; van Hengstum \& Scott, 2009, 2012).

The objective of this study is the characterization of the sediments present in Cova des Pas de Vallgornera, to help understanding their origin as well as their role in the evolutionary history of this coastal cave, highlighting the main differences with those deposits commonly encountered in continental settings.

\section{COVA DES PAS DE VALLGORNERA}

\section{Regional and geological setting}

The studied cave is developed in Upper Miocene limestones and calcarenites that crop out along the southern and eastern areas of Mallorca. The landscape surrounding the cave is characterized by a flat surface, which is the result of progradation during the Upper Miocene times of a well-developed carbonate platform deposited in a reef environment (Pomar, 1991). This flat surface is shaped by significant karst phenomena, including Miocene paleokarst features, littoral karren, fluvio-karst, and poor development of a terra rossa soil that host a "garriga" shrub-land type vegetation characteristic of the Mediterranean climate with low rainfall (Ginés et al., 2012).

The conspicuous horizontal topography of this carbonate platform is only cut by ravines. Scarce ephemeral streams form deep entrances at the coastline (bights or coves) result of the quaternary fluvial incision during glacial low-stands and the posterior flooding and sediment infill related to highstand interglacial periods. The flat surface contrasts, at the coastline, with the prominent vertical cliffs, more than $20 \mathrm{~m}$ height, that characterize most of the coastline (Gómez-Pujol et al., 2013) and where a Neogene (Upper Miocene reef calcarenites) to Quaternary sequence (mainly composed of eolianites) can be clearly observed.

From a geological point of view, the island of Mallorca is included in the complex geological setting of the western Mediterranean. Their geomorphological appearance derives from the compressive phase that started in the Paleogene (the Alpine orogeny) attaining its maximum during the Middle Miocene (Gelabert et al., 1992; Sàbat et al., 2011). Following this compressive phase, a period of extension occurred during the Upper Miocene, creating a series of horsts and grabens. From a physiographical perspective the horsts consist of two subparallel mountain ranges orientated NE-SW, along with a series of small hills located in between. The grabens developed on the foreland of these ranges and were filled by sediments of Middle Miocene to Quaternary age (Fornós et al., 2002). All the Neogene deposits onlap the irregular alpine folded and thrusted basement composed by Mesozoic dolomites and limestones with minor marl intercalations (Pomar et al., 1996).

During the Upper Miocene, the folded areas (the previously cited horsts) remained above sea level whereas a surrounding epicontinental sea covered the rest of the current island. Climate and sea temperature during the Tortonian-Messinian favored the development and progradation of a coral reef environment resulting in a thick slab $(70 \mathrm{~m}$ than occasionally exceed $120 \mathrm{~m}$ ) of alternating calcilutites and very porous calcarenites with a complex geometry (Pomar, 1991). This carbonate platform is delimited by the presence of an important erosive surface with paleokarst features due to the extreme recession that the Mediterranean experienced during the Late Messinian. Above this erosive surface, the reef platform ends with a series of Late Messinian carbonate tabular deposits, which correspond to a sand shoal environment with oolitic sand bars and mangrove facies. In physiographical terms the Upper Miocene carbonate platform constitutes the postorogenic tableau that surrounds the folded reliefs of southeastern Mallorca. This physiographical unit, which is rich in karst phenomena, is where the cavity under study was developed. The Pliocene marine transgressions only covered the lowland areas of the island of Mallorca and in terms of cave development are envisaged as the main speleogenetic phases in Cova des Pas de Vallgornera, according to Ginés et al. (2014). The Pleistocene glacial cycles imply the succession of high sea-stands and sea level recessions of up to -135 m (Butzer and Cuerda, 1962) that complete the geological history of the area leading to the deposition of a sequence of marine and eolian sediments (Fornós et al., 2002, 2009a; Ginés et al., 2012).

A detailed description of the geology of the Vallgornera area can be obtained in Ginés et al. (2014).

\section{Cave location and description}

The Cova des Pas de Vallgornera is located in the Marina de Llucmajor (Migjorn region, southeastern Mallorca), near the touristic bight of Cala Pi (coordinates UTM/WGS84: 489,120; 4,357,510). The artificial entrance of the cave is located $25 \mathrm{~m}$ above the sea level and some $0.5 \mathrm{~km}$ from the coast (Fig. 1). The cave consists of a complex network of breakdown chambers and joint guided phreatic passages developed forming two main tiers (Merino et al., 2014a). At present, over $74 \mathrm{~km}$ of passages have been surveyed, including over $17 \mathrm{~km}$ of underwater passages (Gràcia et al., 2009). 


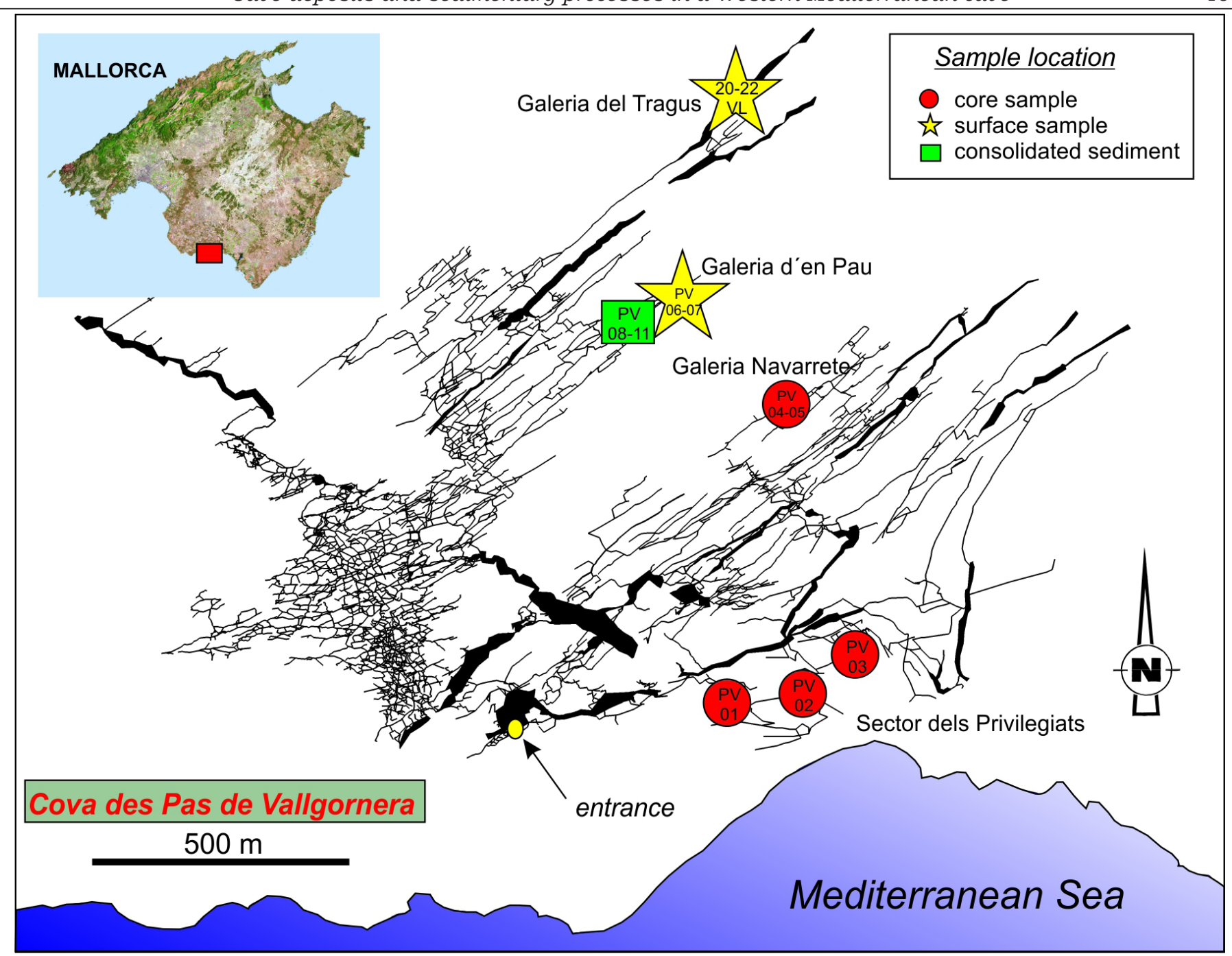

Fig. 1. Map of Cova des Pas de Vallgornera showing the location and the different types of sampled sediments.

The cave pattern is quite variable, being controlled by the textural and lithological characteristics of the carbonate substrate (due to the different sedimentary sub-environments of the Miocene reef) where the cave system is developed (Ginés et al., 2009b, 2014).

Besides the dominant labyrinthine pattern in its southwestern section, it is conspicuous that the presence of rectilinear main passages form the inner part of the cave running relatively parallel from SW to NE. These galleries are structurally controlled by major joints.

The lower parts of the cave are occupied by brackish pools, whose surfaces rise or fall with tidal and/or barometric fluctuations of the sea level. The underwater explorations have revealed the presence of a vast series of galleries below the present-day water table. These flooded passages change the dominant NE-SW direction to N-S near the coastline (Sector dels Privilegiats in Fig. 1).

The presence of spectacular speleothems and solution morphologies is a notable aspect of this cave. Among a great miscellany of vadose speleothems (Merino et al., 2014b), noticeable carbonate precipitation linked to the current water-table (POS: phreatic overgrowths on speleothems, Ginés et al., 2012) occurs in pools at the present sea-level. Relict phreatic overgrowths occur at former water-table levels which were in turn controlled by Quaternary sea-level oscillations (Tuccimei et al., 2006). The dominant deposits of calcite and aragonite associated with these vadose and epiphreatic speleothems contrast with the presence of less common mineralogies, including celestine, strontianite, barite among others (Merino et al., 2009; Onac et al., 2014) present in the form of weathering crusts as well as other precipitates rich in $\mathrm{Fe}$ and $\mathrm{Mn}$. These deposits seem related to hypogenic processes (in the sense of Klimchouk, 2009) that have occurred during some phases in the speleogenetic evolution of the cave, explained by a deep recharge through extensional faults from the Mesozoic basement; this deep-seated recharge yielded abundant solutional features in the cave walls as sharp ascending solutional grooves, rounded rising channels developed from lateral feeding points, cupolas, etc. (Ginés et al., 2009a, 2014; Fornós et al., 2011).

A small part of the cave floors are covered by muddy and/or sandy sediments that, in a wide sense, are marked by two well differentiated characteristics. Two dominant types of sediment are present: fine red siliciclastic muds and yellowish carbonate-dominated mud and sand. The mixture of both materials is also frequent as well as the accumulation of debris due to the collapse of roof and cave walls. The underwater passages are characterized by the presence of $\mathrm{Fe}$ and Mn-rich sediments.

The speleogenesis of the system corresponds, besides the drainage of meteoric diffuse recharge, to 
the mixing processes between continental and marine waters, which affected the Miocene calcarenites and provoked an important void creation, particularly in the very porous reef front carbonates (Ginés et al., 2014). Subsequently, breakdown processes were induced by the glacioeustatic sea level falls generating large block accumulations along with spectacular speleothem ornamentation that decorates almost the entire cave. The recognition of a series of non-functional hypogene features (Ginés et al., 2009a; Merino et al., 2011) brings a third speleogenetic agent, the hypogene basal recharge related to local geothermal phenomena (López $\&$ Mateos, 2006) that was also involved in the genesis of this coastal cave system.

\section{METHODS}

To characterize the sediments present in the galleries of Cova des Pas de Vallgornera standard sedimentological and geochemical analyses were carried out on all the collected samples.

Sediment samples were collected when available in different sectors of the cave (Fig. 1). In Galeria d'en Pau six samples were collected at the floor surface, while in Galeria del Tragus seven more samples were collected in the different profiles of the sediment accumulation exposures.

Additionally, a series of three push cores (Table 1) were obtained by scuba-divers in the underwater passages of Sector dels Privilegiats. Cores were drilled by forcing a PVC pipe, $5 \mathrm{~cm}$ in diameter and $50 \mathrm{~cm}$ long, until the bedrock was reached. Furthermore, in the air-filled passages of Galeria Navarrete two more cores were taken. Cores obtained were bagged, sealed, numbered, and brought back to the Earth Sciences Department of the Universitat de les Illes Balears, where they were opened, longitudinally sectioned, photographed and sampled in stratigraphic order according to the different observed levels (18 subsamples for the underwater cores and 11 in the case of the cores from the air-filled galleries). Presence of sedimentary structures, such as laminations, and other general observations were annotated for all the cases.

A total of 42 samples were processed in the laboratory where each sediment sample was air-dried for $24 \mathrm{~h}$ prior to analysis. After the color was determined by means of the MUNSELLC soil color chart, grain-size, mineralogy, geochemistry, and organic matter were determined.

As all sediments showed $<2 \mathrm{~mm}$-particle size, grain size analysis was made using a Malvern Mastersizer 2000. Elemental particle parameters were calculated using the Gradistat ver. 8 software (Blott \& Pye, 2001). Cumulative curves, frequency histograms, and statistical parameters such as mean, sorting, kurtosis and skewness were obtained following the geometric graphical method of Folk \& Ward (1957).

Randomly oriented powders of the bulk samples of sediments were used for the mineralogical analysis. After sample pre-treatment with $\mathrm{H}_{2} \mathrm{O}_{2}$ to remove organic matter, mineralogy of sediments was determined with a Siemens D-5000 X-ray diffractometer using Cu
Table 1. Samples location.

\begin{tabular}{|l|c|l|l|}
\hline sample & subsample & type & location (survey point) \\
\hline PV-01 & a - $f$ & core (underwater) & Sector dels Privilegiats (10115) \\
\hline PV-02 & a - $f$ & core (underwater) & Sector dels Privilegiats (10133) \\
\hline PV-03 & a - $f$ & core (underwater) & Sector dels Privilegiats (10177) \\
\hline PV-04 & a - e & core & Galeria Navarrete (7265) \\
\hline PV-05 & a - $f$ & core & Galeria Navarrete (7265) \\
\hline PV-06 & & surface sample & $\begin{array}{l}\text { Galeria d'en Pau (1836 - Sala } \\
\text { de les Anastomosis) }\end{array}$ \\
\hline PV-07 & & surface sample & $\begin{array}{l}\text { Galeria d'en Pau (1837 - Sala } \\
\text { de les Anastomosis) }\end{array}$ \\
\hline PV-08 & & consolidated sediment & Galeria d'en Pau (640) \\
\hline PV-09 & & consolidated sediment & Galeria d'en Pau (640-639) \\
\hline PV-10 & & consolidated sediment & Galeria d'en Pau (639) \\
\hline PV-11 & & consolidated sediment & Galeria d'en Pau (639) \\
\hline 20-22-1 & & surface sample & Galeria del Tragus \\
\hline 20-22-2 & & surface sample & Galeria del Tragus \\
\hline 20-22-3 & & surface sample & Galeria del Tragus \\
\hline 20-22-4 & & surface sample & Galeria del Tragus \\
\hline VL-M115 & & surface sample & Galeria del Tragus \\
\hline VL-M116 & & surface sample & Galeria del Tragus \\
\hline VL-M117 & & surface sample & Galeria del Tragus \\
\hline
\end{tabular}

$\mathrm{K} \alpha$ radiation. The pressed powder diffraction patterns were recorded from $3^{\circ}$ to $65^{\circ} 2 \theta$ in steps of $0.03^{\circ}, 0.3-\mathrm{s}$ counting time per step, at $25^{\circ} \mathrm{C}$ room temperature, and logged to data files for analysis.

Phase determination and semi-quantitative analysis were made by the X-Powder ver.2010.01.09 Pro software using the DifData database (Downs \& HallWallace, 2003).

All samples were observed by SEM (Hitachi E S-3400N) and analyzed by EDX (Bruker X-Falsh Detector 4020) for their bulk sediment geochemistry. Major elements in their oxidized state (such as $\mathrm{MgO}, \mathrm{SiO}_{2}, \mathrm{CaO}, \mathrm{MnO}, \mathrm{FeO}$, $\mathrm{K}_{2} \mathrm{O}, \mathrm{Al}_{2} \mathrm{O}_{3}, \mathrm{SO}_{3}, \mathrm{TiO}_{2}, \mathrm{P}_{2} \mathrm{O}_{3}$ and $\mathrm{Na}_{2} \mathrm{O}$ ) were determined as a percentage weight composition.

To estimate the organic matter content, the samples were weighted after drying at $105^{\circ} \mathrm{C}$, then heated at $360^{\circ} \mathrm{C}$ for 2 hours and weighed again. The final value was reported as \% LOI (Schulte \& Hopkins, 1996).

\section{SEDIMENT CHARACTERISTICS WITHIN THE CAVE SYSTEM}

The Cova des Pas de Vallgornera has slight differences in the sediment characteristics as well as in processes involved when compared with other previously described caves within the littoral karst of the Mallorca Island (Gràcia et al., 2003, 2005, 2007; Fornós et al., 2009b). Most Mallorcan caves have natural entrances created by breakdown and collapse intersecting the surface, allowing the ingress of external sediments. In the present case, the cave does not currently have any natural entrance although in the past several entrances may have existed as revealed by the presence of vertebrate paleontological remains (Bover et al., 2014). As a consequence, significant allogenic detrital sedimentation is not currently a relevant phenomenon in any section of the cave system. The muddy sediments are scarce, but present in the galleries of the innermost part of the cave as patchy accumulations few centimeters 
in thickness, both in the terrestrial and underwater passages. The autochthonous sediments are similar to those previously described in Mallorcan coastal caves (Fornós et al., 2009b), frequently featuring a mixed sedimentation that includes carbonate particles of rock detached from the walls, together with the scarce allochtonous clay and silt deposits derived from the infiltration of soil materials to the underlying voids.

In the next paragraphs we describe the sediments existing in four different areas of the cave, where their presence is conspicuous and illustrative of the represented sedimentary facies as well as the processes that act or have acted in the cave along its speleogenetic evolution.

\section{Sediments in Sector dels Privilegiats}

Galleries and conduits that form the Sector dels Privilegiats (Fig. 1) correspond to the underwater passages nearest to the sea. Despite the general lack of sediments characteristic of most galleries and chambers of the cave, in some parts of these passages extensive sedimentary accumulations can be observed. Three sediment cores (Fig. 2), located in a SW-NE section of one of the nearest parallel galleries to the coastline, were obtained reaching a maximum thickness of $35 \mathrm{~cm}$. Due to the difficulties during the sampling procedures as well as the absence of clear sediments exposures it has been impossible to know the real thickness of these extensive but irregular deposits.

In general they are composed by abundant but isolated rock fragments embedded in a dark silty sand matrix. The color of sediments (Table 2) ranges from dark reddish brown (5YR3/2) to brownish yellow (10YR6/6). The sand is the predominant texture with a mean greater than $50 \%$ while the mud represents around $40 \%$.
The organic content (LOI) of these underwater sediments is the highest of all collected sediments in the entire cave, reaching a maximum of $10.27 \%$ in core PV-02 and a minimum on top of all cores (lowest value of $4.03 \%$ ). The mean for the entire sampled cores in this area is around 6\%.

One of the main differences with the rest of the cave sediments, reflected in their color, corresponds to their chemical composition (Table 3). They are rich in Fe-Mn sediments. FeO is the dominant oxide composition with mean values slightly higher than $45 \%$ that range from 14.62 to $72.13 \%$ and the $\mathrm{MnO}$ composition has a mean near to $11 \%$, with values ranging from 5.96 to $18.56 \%$ (Table 4 ).

Clay minerals dominate the sediment compositon, representing more than $40 \%$. The main phylosilicates, kaolinite (near 23\%) and illite (around 13\%) are in the highest proportion, although other minerals (e.g. montmorillonite and palygorskite) are also present. Goethite represents $15 \%$ and the elevated proportion (near 20\%) of amorphous material can be correlated with the presence of Mn-oxides and hydroxides not detected in the XRD analysis due their low crystallinity.

Grain size, as commented before, corresponds to a muddy sand. All the samples show similar values and no sequence trend can be observed on them. Silt represents near the $40 \%$, and clay has values around $3.5 \%$. The sand fraction is dominated by medium to very fine textures. The sediments of Sector dels Privilegiats show the poorest sorting (Table 5) of all the sediments represented in the cave.

Sediment accumulation in this sector represents a complex mixing of sediments with different mineralogies and chemistry that suggests a complex convergence of sedimentary processes. Besides the fine material infiltrated from the soil during

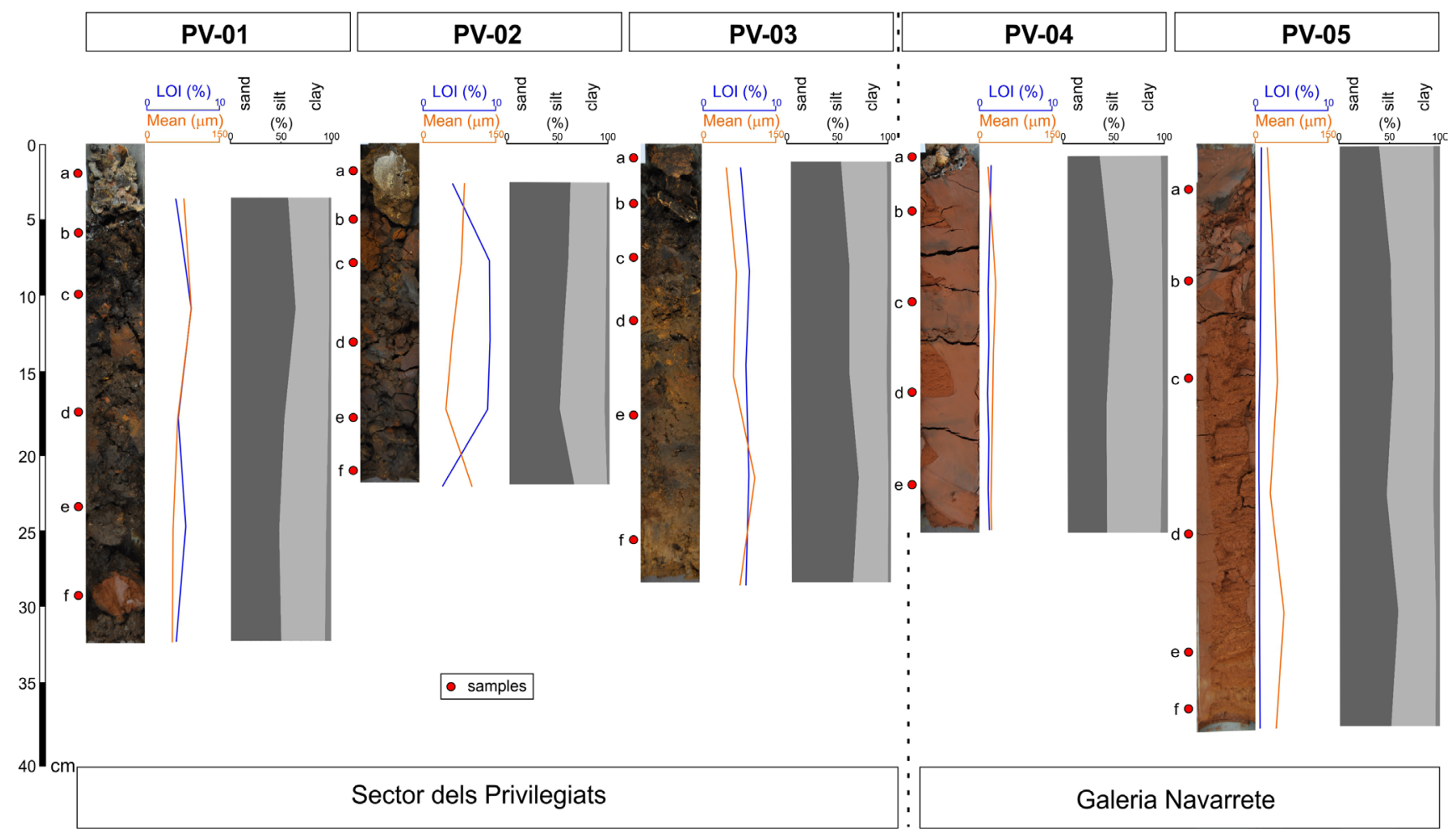

Fig. 2. Cores of sedimentary infilling from Cova des Pas de Vallgornera showing the position of the analyzed samples (red dots) and the LOI and particle size analysis (see location on Fig. 1). 
flooding episodes (layers with elevated concentration of quartz, feldspars, and clay minerals as kaolinite or palygorskite, mainly derived from dust rains as observed by Fiol et al., 2005 and Muhs et al., 2010)

Table 2. Cave sediments sample description, grain size distribution and LOI.

\begin{tabular}{|c|c|c|c|c|c|}
\hline SAMPLE & Description & $\%$ gravel & $\%$ sand & $\%$ mud & $\%$ LOI \\
\hline \multicolumn{6}{|c|}{ Galeria del Tragus } \\
\hline $20-22-1$ & 7YR7/4 - Pink clayey silt & 0 & 33.9 & 66.1 & 3.3 \\
\hline $20-22-2$ & $\begin{array}{l}\text { 7YR6/6 - Reddish yellow } \\
\text { clayey silt }\end{array}$ & 0 & 31.9 & 68.1 & 2.19 \\
\hline $20-22-3$ & 5YR5/6 - Yellowish red sand & 0 & 84.9 & 15.1 & 0.63 \\
\hline $20-22-4$ & 7YR6/4 - Light brown silty sand & 0 & 64.9 & 35.1 & 1.41 \\
\hline VL-M115 & $\begin{array}{l}\text { 5YR5/6 - Yellowish red silty } \\
\text { sand }\end{array}$ & 0 & 74.4 & 25.6 & 1.61 \\
\hline VL-M117 & 5YR5/6 - Yellowish red silt & 0 & 15.8 & 84.2 & 1.2 \\
\hline \multicolumn{6}{|c|}{ Sector dels Privilegiats (underwater) } \\
\hline PV-01a & 5YR6/3 - Carbonate cust & - & - & - & - \\
\hline PV-01b & 5YR2.5/1 - Black silty sand & 0 & 57.1 & 42.9 & 4.03 \\
\hline PV-01c & 5YR3/1 - Dark grey silty sand & 0 & 64.6 & 35.4 & 5.66 \\
\hline PV-01d & $\begin{array}{l}\text { 5YR3/2 - Dark reddish brown } \\
\text { sandy silt }\end{array}$ & 0 & 53.3 & 46.7 & 4.38 \\
\hline PV-01e & $\begin{array}{l}\text { 5YR2.5/2 -Dark reddish brown } \\
\text { sandy silt }\end{array}$ & 0 & 48.1 & 51.9 & 5.25 \\
\hline PV-01f & $\begin{array}{l}\text { 5YR5/6 - Yellowish red silty } \\
\text { sand }\end{array}$ & 0 & 50.2 & 49.8 & 4.16 \\
\hline PV-02a & 5YR5/4 - Carbonate cust & & & & \\
\hline$P V-02 b$ & $\begin{array}{l}\text { 5YR4/4 - Reddish brown silty } \\
\text { sand }\end{array}$ & 0 & 61.2 & 38.8 & 4.61 \\
\hline PV-02c & 7.5YR5/8 - Brown silty sand & 0.1 & 59 & 40.9 & 10.1 \\
\hline PV-02d & 7.5YR5/8 - Brown silty sand & 0 & 54.2 & 45.8 & 10.27 \\
\hline PV-02e & $\begin{array}{l}\text { 5YR4/4 - Reddish brown silty } \\
\text { sand }\end{array}$ & 0 & 50.4 & 49.6 & 9.78 \\
\hline PV-02f & 7.5YR5/6 - Brown nodular sand & 0 & 65 & 35 & 2.95 \\
\hline PV-03a & 5YR6/3 - Carbonate cust & - & - & - & - \\
\hline PV-03b & $\begin{array}{l}\text { 10YR3/2 - Dark grayish brown } \\
\text { sandy silt }\end{array}$ & 0 & 49.9 & 50.1 & 5.67 \\
\hline PV-03c & $\begin{array}{l}\text { 10YR6/8 - Brownish yellow } \\
\text { silty sand }\end{array}$ & 0 & 58.5 & 41.5 & 6.76 \\
\hline PV-03d & $\begin{array}{l}\text { 10YR } 4 / 4 \text { - Dark yellowish brown } \\
\text { silty sand }\end{array}$ & 0 & 58.3 & 41.7 & 6.42 \\
\hline PV-03e & $\begin{array}{l}\text { 10YR3/2 - Dark grayish brown } \\
\text { sand }\end{array}$ & 0 & 67.9 & 32.1 & 6.89 \\
\hline PV-03f & 10YR6/6 - Brownish yellow sand & 0 & 62.1 & 37.9 & 6.31 \\
\hline \multicolumn{6}{|c|}{ Galeria Navarrete } \\
\hline PV-04a & 5YR6/3 - Carbonate cust & & & & \\
\hline PV-04b & 2.5YR4/6 - Dark red clayey silt & 0 & 31.8 & 68.2 & 1.34 \\
\hline PV-04c & 2.5YR4/6 - Dark red silt & 0 & 45.1 & 54.9 & 1.07 \\
\hline PV-04d & 2.5YR4/6 - Dark red clayey silt & 0 & 38.7 & 61.3 & 0.85 \\
\hline PV-04e & 2.5YR4/6 - Dark red clayey silt & 0 & 39.4 & 60.6 & 1.09 \\
\hline PV-05a & 2.5YR4/6 - Dark red clayey silt & 0 & 39 & 61 & 0.45 \\
\hline PV-05b & 2.5YR4/6 - Dark red sandy silt & 0 & 50.7 & 49.3 & 0.49 \\
\hline PV-05c & 2.5YR4/8 - Dark red sandy silt & 0 & 53.3 & 46.7 & 0.23 \\
\hline PV-05d & 2.5YR5/6 - Red sandy silt & 0 & 46.9 & 53.1 & 0.11 \\
\hline PV-05e & 2.5YR5/6 - Red silty sand & 0 & 58.6 & 41.4 & 0.22 \\
\hline PV-05f & 2.5YR6/6 Red silty sand & 0 & 51.4 & 48.6 & 0.21 \\
\hline \multicolumn{6}{|c|}{ Galeria d'en Pau } \\
\hline PV-06 & $\begin{array}{l}\text { 2.5YR3/4 - 10R4/8 Dusky red } \\
\text { sands and silts }\end{array}$ & 0 & 64.5 & 35.5 & 3.77 \\
\hline PV-07 & $2.5 Y R 3 / 3$-Dusky red silty sand & 0 & 59.6 & 40.4 & 5.49 \\
\hline PV-08 & 5YR2.5/1 - Black cemented silt & - & - & - & - \\
\hline PV-09 & $\begin{array}{l}\text { 10YR } 8 / 3 \text { - Pale brown cemented } \\
\text { sand }\end{array}$ & - & - & - & - \\
\hline PV-10 & $\begin{array}{l}\text { 5YR6/8 - Reddish yellow } \\
\text { cemented silty sand }\end{array}$ & - & - & - & - \\
\hline PV-11 & $\begin{array}{l}7.5 Y R 7 / 8 \text { - Reddish yellow } \\
\text { sands }\end{array}$ & - & - & - & - \\
\hline
\end{tabular}

reaching these submerged passages, processes of wall corrosion and detachment of carbonate particles that may attain gravel size, are evident especially in core PV-01. Their deposition shows a characteristic longitudinal accumulation of sediments along the floor of the phreatic conduits (Fig. 3), following the projection of the cave walls. Mud cracks are evident on top of most of these deposits, as well as a carbonate crust deposited during an air-filled period.

\section{Sediments in Galeria Navarrete}

The most important accumulation of muddy detrital red sediments is found at Galeria Navarrete. Although accumulations of around $20 \mathrm{~cm}$ in thickness are the most common, others reaching nearly $40 \mathrm{~cm}$ can be observed thanks to the sediment cores made on their floor (Fig. 2). Mineralogical composition of sediments is characterized by the main presence of silicic minerals and the scarcity of carbonates (Table 4). The beds on top of the deposits exhibit abundant mud cracks showing a black Fe-Mn rich patina on them (Fig. 4).

From the detailed observation of sediment cores, a thin horizontal plane-parallel lamination less than $1 \mathrm{~mm}$ thick can be observed due to small changes in color and small grain size differences. The sedimentary accumulation is made up of well sorted finegrained detrital sediments, predominantly silts with subordinate very fine sands. They show a color that ranges from dark red $(2.5 \mathrm{YR} 4 / 6)$ in the siltiest levels to red $(2.5 Y R 5 / 6)$ when very fine sand predominates.

Globally, the grain size is mainly composed of a silt fraction representing around $50 \%$ of the total, whereas the fine to very fine sands represent nearly $38 \%$. The clay fraction does not reach the 6\%. Although the percentages of sand and mud vary along the sampled cores (Table 2), it seems quite evident that the upper levels of the sequence have a mean grain size slightly inferior to the lower ones. The complete deposit shows a fining upwards sequence and a poor sorting. All the statistical parameters related with the grain size can be viewed on Table 5 .

The organic content of the sediments is the smallest of all collected samples in the entire cave,

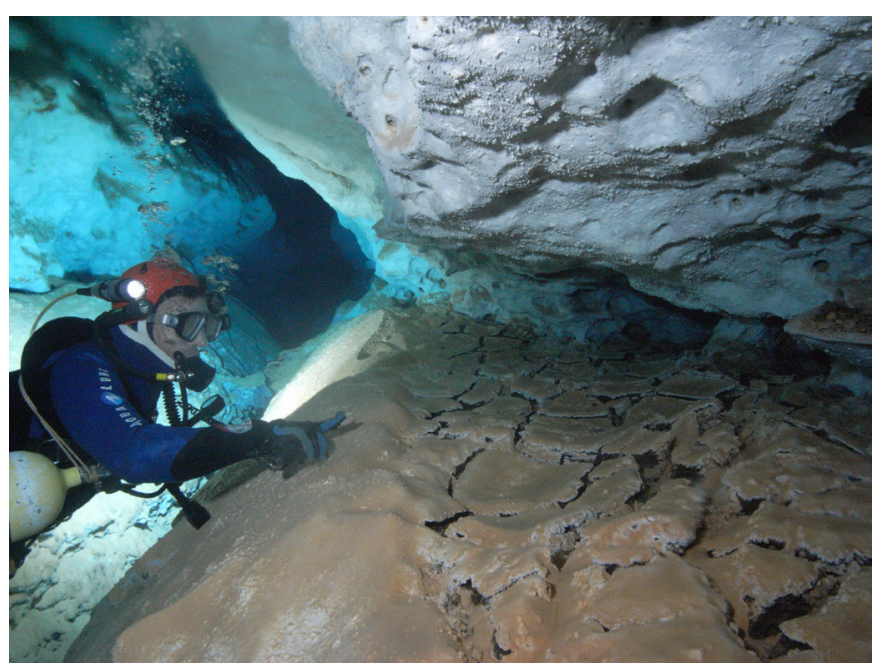

Fig. 3. Longitudinal accumulation of grains detached from the cave walls and presence of mud cracks through the phreatic conduits of Sector dels Privilegiats (photo: Jaume Pocoví). 
Table 3. Major elemental data of cave sediments expressed as wt. \%.

\begin{tabular}{|c|c|c|c|c|c|c|c|c|c|c|c|}
\hline Sample & $\mathrm{MgO}$ & $\mathrm{SiO}_{2}$ & $\mathrm{CaO}$ & $\mathrm{MnO}$ & $\mathrm{FeO}$ & $\mathrm{K}_{2} \mathrm{O}$ & $\mathrm{Al}_{2} \mathrm{O}_{3}$ & $\mathrm{SO}_{3}$ & $\mathrm{TiO}_{2}$ & $\mathrm{P}_{2} \mathrm{O}_{3}$ & $\mathrm{Na}_{2} \mathrm{O}$ \\
\hline \multicolumn{12}{|c|}{ Galeria del Tragus } \\
\hline $20-22-1$ & 3.55 & 50.94 & 7.22 & 0.00 & 7.43 & 3.09 & 18.60 & 0.00 & 1.04 & 0.81 & 1.10 \\
\hline $20-22-2$ & 1.74 & 32.09 & 24.50 & 0.00 & 5.47 & 3.18 & 10.08 & 0.00 & 0.85 & 0.56 & 0.14 \\
\hline $20-22-3$ & 3.94 & 41.97 & 24.84 & 0.00 & 5.25 & 2.41 & 11.90 & 0.00 & 0.76 & 0.72 & 0.99 \\
\hline $20-22-4$ & 3.93 & 35.86 & 24.49 & 0.00 & 6.30 & 2.75 & 14.61 & 0.00 & 0.00 & 0.79 & 1.13 \\
\hline VL-M115 & 2.99 & 32.50 & 38.86 & 0.00 & 4.73 & 2.28 & 9.93 & 0.00 & 0.73 & 0.00 & 0.68 \\
\hline VL-M116 & 2.67 & 31.99 & 26.72 & 0.00 & 6.10 & 2.75 & 11.04 & 0.00 & 0.67 & 0.57 & 0.16 \\
\hline VL-M117 & 2.88 & 44.69 & 23.98 & 0.00 & 5.00 & 2.12 & 12.26 & 0.00 & 0.72 & 0.86 & 0.95 \\
\hline \multicolumn{12}{|c|}{ Sector dels Privilegiats (underwater) } \\
\hline PV-01a & 19.80 & 3.83 & 42.47 & 2.73 & 5.54 & 0.55 & 2.68 & 2.07 & 0.00 & 0.82 & 0.00 \\
\hline PV-01b & 3.40 & 11.48 & 10.42 & 18.56 & 22.09 & 1.68 & 5.79 & 2.73 & 0.84 & 0.73 & 0.00 \\
\hline PV-01c & 2.52 & 8.93 & 4.94 & 16.14 & 32.26 & 1.47 & 5.24 & 3.69 & 0.00 & 0.90 & 0.00 \\
\hline PV-01d & 2.99 & 10.54 & 5.97 & 12.16 & 33.77 & 1.24 & 5.83 & 3.38 & 0.64 & 0.60 & 0.00 \\
\hline PV-01e & 2.35 & 7.18 & 2.44 & 10.59 & 49.19 & 1.27 & 4.39 & 3.70 & 0.00 & 0.54 & 0.00 \\
\hline PV-01f & 2.53 & 4.50 & 1.38 & 5.96 & 66.73 & 0.43 & 3.08 & 0.00 & 0.00 & 0.77 & 0.00 \\
\hline PV-02a & 2.45 & 9.79 & 29.26 & 10.32 & 14.62 & 1.45 & 5.65 & 3.05 & 0.00 & 1.75 & 0.00 \\
\hline$P V-02 b$ & 2.48 & 7.77 & 17.33 & 13.54 & 28.68 & 1.24 & 4.40 & 3.91 & 0.00 & 1.88 & 0.00 \\
\hline PV-02c & 1.99 & 1.70 & 1.48 & 6.88 & 72.13 & 0.62 & 1.73 & 0.00 & 0.00 & 0.83 & 0.00 \\
\hline$P V-02 d$ & 2.88 & 3.23 & 1.14 & 8.86 & 61.70 & 0.32 & 3.42 & 0.00 & 0.00 & 0.00 & 0.00 \\
\hline PV-02e & 2.09 & 2.21 & 1.01 & 12.85 & 59.05 & 0.69 & 2.25 & 3.02 & 0.00 & 0.64 & 0.00 \\
\hline PV-02f & 2.83 & 4.86 & 12.80 & 11.24 & 42.56 & 0.76 & 3.49 & 4.64 & 0.00 & 1.57 & 0.00 \\
\hline PV-03a & 7.79 & 9.32 & 23.91 & 9.37 & 18.39 & 0.92 & 5.02 & 0.00 & 0.00 & 1.51 & 0.00 \\
\hline PV-03b & 2.04 & 3.56 & 2.03 & 8.64 & 61.31 & 0.76 & 2.88 & 2.95 & 0.00 & 0.71 & 0.00 \\
\hline PV-03c & 2.56 & 6.70 & 4.87 & 12.14 & 49.42 & 0.74 & 4.75 & 2.26 & 0.00 & 1.77 & 0.00 \\
\hline PV-03d & 2.36 & 5.12 & 5.26 & 13.51 & 53.01 & 1.21 & 4.01 & 2.40 & 0.00 & 1.83 & 0.00 \\
\hline PV-03e & 2.38 & 6.14 & 6.02 & 7.43 & 50.09 & 1.05 & 4.83 & 2.80 & 0.00 & 1.75 & 0.00 \\
\hline PV-03f & 2.29 & 6.81 & 6.91 & 8.58 & 50.79 & 1.07 & 4.60 & 2.26 & 0.00 & 1.80 & 0.00 \\
\hline \multicolumn{12}{|c|}{ Galeria Navarrete } \\
\hline PV-04a & 2.44 & 35.06 & 10.73 & 3.40 & 12.94 & 4.41 & 18.04 & 0.00 & 1.07 & 0.17 & 0.00 \\
\hline PV-04b & 2.52 & 50.01 & 0.00 & 0.00 & 9.28 & 4.27 & 22.66 & 0.00 & 1.48 & 0.00 & 0.93 \\
\hline PV-04c & 2.52 & 49.71 & 0.00 & 0.00 & 10.38 & 4.16 & 23.09 & 0.00 & 1.46 & 0.00 & 1.01 \\
\hline PV-04d & 2.81 & 55.75 & 0.54 & 1.03 & 9.02 & 4.10 & 23.29 & 0.00 & 1.30 & 0.00 & 0.00 \\
\hline PV-04e & 2.36 & 48.26 & 0.00 & 0.00 & 8.62 & 4.15 & 21.80 & 0.00 & 1.45 & 0.00 & 0.00 \\
\hline PV-05a & 2.35 & 46.45 & 0.00 & 0.00 & 8.85 & 4.06 & 21.02 & 0.00 & 1.45 & 0.00 & 0.91 \\
\hline$P V-05 b$ & 2.45 & 53.58 & 0.00 & 0.00 & 8.90 & 4.19 & 20.88 & 0.00 & 1.51 & 0.00 & 1.03 \\
\hline PV-05c & 2.22 & 45.09 & 0.00 & 0.00 & 8.40 & 3.55 & 20.46 & 0.00 & 1.72 & 0.00 & 0.99 \\
\hline PV-05d & 2.60 & 50.80 & 0.00 & 0.00 & 9.60 & 4.13 & 22.72 & 0.00 & 1.34 & 0.00 & 0.00 \\
\hline PV-05e & 2.17 & 54.15 & 0.00 & 0.00 & 10.13 & 4.33 & 21.50 & 0.00 & 1.21 & 0.00 & 0.00 \\
\hline$P V-05 f$ & 2.55 & 57.49 & 0.00 & 0.00 & 8.55 & 3.92 & 23.76 & 0.00 & 1.18 & 0.00 & 0.00 \\
\hline \multicolumn{12}{|c|}{ Galeria d'en Pau } \\
\hline PV-06 & 2.24 & 17.25 & 3.98 & 6.71 & 39.10 & 1.70 & 8.78 & 0.00 & 0.00 & 1.68 & 0.00 \\
\hline PV-07 & 1.75 & 9.66 & 12.15 & 6.20 & 40.52 & 1.35 & 8.95 & 0.00 & 0.00 & 5.84 & 0.70 \\
\hline PV-08 & 0.80 & 2.50 & 48.40 & 15.77 & 14.64 & 0.97 & 1.31 & 0.00 & 0.00 & 0.37 & 0.00 \\
\hline PV-09 & 5.38 & 9.21 & 48.11 & 1.19 & 14.82 & 1.20 & 5.23 & 0.00 & 0.00 & 0.79 & 0.00 \\
\hline PV-10 & 1.54 & 6.28 & 19.87 & 6.76 & 49.94 & 0.00 & 1.37 & 0.00 & 0.00 & 0.54 & 0.00 \\
\hline PV-11 & 0.82 & 3.25 & 57.55 & 3.11 & 20.20 & 0.67 & 0.95 & 0.00 & 0.00 & 0.54 & 0.00 \\
\hline
\end{tabular}

reaching a maximum of $1.34 \%$ in the top level and a minimum of $0.11 \%$ at the base. The mean for the entire column is $0.61 \%$.

Mineral composition of sediments (Table 4) is dominated by quartz with a mean of $61.9 \%$ and feldspars (18.3\%), the carbonates, mainly Mg-calcite, are poorly represented barely reaching the $6 \%$ (mean of $2.4 \%$ ). Total clay minerals are around the $14 \%$ mostly represented by illite and kaolinite. Locally there are more silty intercalations with illite being more than $10 \%$. Analysis of major chemical elements (Table 3) corroborates the aforementioned mineralogy.
The sediments here are interpreted as classical slackwater sediments, characteristic of maze caves (Bosch \& White, 2004), deposited in very low flow velocities. Moreover, the autochthonous muddy sedimentation is not very common through the whole cave. This is probably due to the high purity of the Upper Miocene limestone with less than 1\% insoluble residue (Fornós et al., 2009b). In the case of Cova des Pas de Vallgornera, the host rock is extremely pure (in lagoon facies the impurities represent $0.38 \%$ and in the reef front facies less than $0.1 \%$, being their main chemical constituents $\mathrm{SiO}_{2}, 40 \% ; \mathrm{Al}_{2} \mathrm{O}_{3}, 17.5 \%$ and $\left.\mathrm{Fe}_{2} \mathrm{O}_{3}, 13.5 \%\right)$. 
As a consequence, most of the fine sediment composition has, at its very beginning, an external origin entering to the system during flooding episodes favored by some openings of the cave. The observed mineralogy similar to the present-day soil composition (Fiol et al., 2005; Muhs et al., 2010) as in other Mediterranean caves (Iacovello \& Martini, 2012) supports this fact. In this case the slackwater facies (Bosch \& White, 2004)

Table 4. Mineralogy of cave sediments (\%). include muddy fine sands transported into the main galleries system as suspended load, which could settle out in secondary passages.

In any case, the slight reduction of the grain size from the base to the top indicates a decrease in the hydrodynamic energy conditions of the cave.

A carbonate crust covers the red muddy sediments (Fig. 4) thus indicating a change in the hydrologic regime that acted in this part of the cave, related to the fact that these passages became situated above the water table

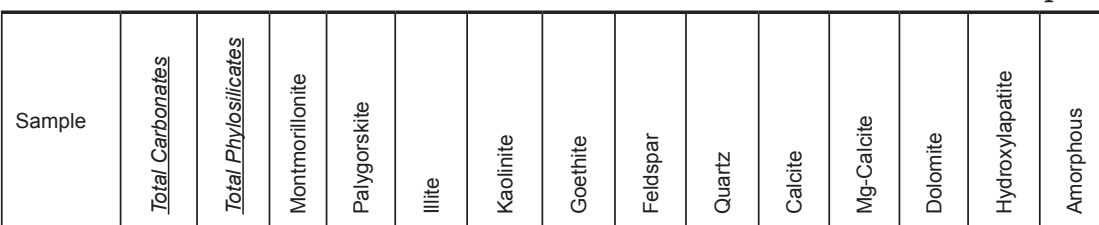

Galeria del Tragus

\begin{tabular}{|c|c|c|c|c|c|c|c|c|c|c|c|c|c|c|}
\hline $20-22-1$ & 12.8 & 10.3 & 0.0 & 0.0 & 4.4 & 5.9 & 0.0 & 18.4 & 53.8 & 10.4 & 0.0 & 2.4 & 0.0 & 4.7 \\
\hline $20-22-2$ & 50.1 & 8.3 & 0.0 & 0.0 & 3.1 & 5.2 & 0.0 & 11.9 & 23.6 & 45.8 & 0.0 & 4.3 & 0.0 & 6.1 \\
\hline $20-22-3$ & 84.2 & 2.0 & 0.0 & 0.0 & 2.0 & 0.0 & 0.0 & 0.0 & 11.9 & 70.3 & 0.0 & 13.9 & 0.0 & 1.9 \\
\hline $20-22-4$ & 47.6 & 9.3 & 0.0 & 0.0 & 3.9 & 5.4 & 0.0 & 13.8 & 21.8 & 38.2 & 0.0 & 9.4 & 0.0 & 7.5 \\
\hline VL-M115 & 55.0 & 4.6 & 0.0 & 0.0 & 1.1 & 3.5 & 0.0 & 3.7 & 32.3 & 39.3 & 0.0 & 15.7 & 0.0 & 4.4 \\
\hline VL-M116 & 56.3 & 5.1 & 0.0 & 0.0 & 1.9 & 3.2 & 0.0 & 6.6 & 26.4 & 42.4 & 0.0 & 13.9 & 0.0 & 5.6 \\
\hline VL-M117 & 31.9 & 9.0 & 0.0 & 0.0 & 5.3 & 3.7 & 0.0 & 10.8 & 44.7 & 27.2 & 0.0 & 4.7 & 0.0 & 3.6 \\
\hline
\end{tabular}

\begin{tabular}{|l|l|l|l|l|l|l|l|l|l|l|l|l|l|l|}
\hline PV-01a & 95.2 & 0.0 & 0.0 & 0.0 & 0.0 & 0.0 & 0.0 & 0.0 & 0.0 & 87.4 & 0.0 & 7.8 & 0.0 & 4.8 \\
\hline
\end{tabular}

\begin{tabular}{|c|c|c|c|c|c|c|c|c|c|c|c|c|c|c|}
\hline$P V-01 b$ & 34.7 & 41.6 & 2.6 & 0.0 & 33.2 & 5.8 & 2.8 & 0.0 & 5.0 & 5.6 & 0.0 & 29.1 & 0.0 & 15.9 \\
\hline
\end{tabular}

\begin{tabular}{|l|l|l|l|l|l|l|l|l|l|l|l|l|l|l|}
\hline PV-01c & 16.0 & 54.2 & 0.0 & 12.7 & 32.4 & 9.1 & 4.2 & 0.0 & 5.4 & 0.0 & 0.0 & 16.0 & 0.0 & 20.2 \\
\hline
\end{tabular}

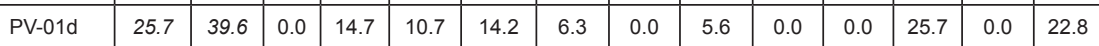

\begin{tabular}{|l|l|l|l|l|l|l|l|l|l|l|l|l|l|l|l|}
\hline PV-01e & 24.9 & 37.8 & 4.2 & 0.0 & 9.7 & 23.9 & 12.4 & 0.0 & 4.0 & 0.0 & 0.0 & 24.9 & 0.0 & 20.9 \\
\hline
\end{tabular}

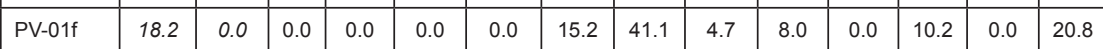

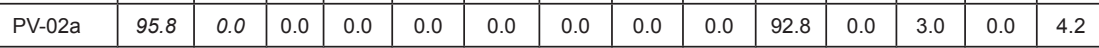

\begin{tabular}{|l|l|l|l|l|l|l|l|l|l|l|l|l|l|l|}
\hline PV-02b & 57.9 & 27.3 & 0.0 & 0.0 & 14.2 & 13.1 & 5.2 & 0.0 & 0.0 & 57.9 & 0.0 & 0.0 & 0.0 & 9.6 \\
\hline
\end{tabular}

\begin{tabular}{|l|l|l|l|l|l|l|l|l|l|l|l|l|l|l|}
\hline PV-02c & 9.1 & 48.5 & 0.0 & 0.0 & 19.7 & 28.8 & 20.9 & 0.0 & 0.0 & 9.1 & 0.0 & 0.0 & 0.0 & 21.5 \\
\hline
\end{tabular}

\begin{tabular}{|l|l|l|l|l|l|l|l|l|l|l|l|l|l|l|}
\hline PV-02d & 9.0 & 47.2 & 0.0 & 0.0 & 17.6 & 29.6 & 20.9 & 0.0 & 0.0 & 0.0 & 9.0 & 0.0 & 0.0 & 22.9 \\
\hline
\end{tabular}

\begin{tabular}{|l|l|l|l|l|l|l|l|l|l|l|l|l|l|l|}
\hline PV-02e & 0.0 & 44.5 & 0.0 & 0.0 & 0.0 & 44.5 & 35.3 & 0.0 & 0.0 & 0.0 & 0.0 & 0.0 & 0.0 & 20.2 \\
\hline
\end{tabular}

\begin{tabular}{|c|c|c|c|c|c|c|c|c|c|c|c|c|c|c|}
\hline PV-02f & 67.4 & 24.1 & 0.0 & 0.0 & 14.7 & 9.4 & 0.0 & 0.0 & 2.6 & 67.4 & 0.0 & 0.0 & 0.0 & 5.9 \\
\hline
\end{tabular}

\begin{tabular}{|l|l|l|l|l|l|l|l|l|l|l|l|l|l|l|}
\hline PV-03a & 95.7 & 0.0 & 0.0 & 0.0 & 0.0 & 0.0 & 0.0 & 0.0 & 0.0 & 0.0 & 78.1 & 17.6 & 0.0 & 4.3 \\
\hline
\end{tabular}

\begin{tabular}{|l|l|l|l|l|l|l|l|l|l|l|l|l|l|l|}
\hline PV-03b & 27.7 & 37.4 & 4.4 & 0.0 & 17.0 & 16.0 & 9.3 & 0.0 & 0.0 & 0.0 & 0.0 & 27.7 & 0.0 & 25.6 \\
\hline
\end{tabular}

\begin{tabular}{|c|c|c|c|c|c|c|c|c|c|c|c|c|c|c|}
\hline PV-03c & 0.0 & 42.6 & 7.9 & 0.0 & 0.0 & 34.7 & 27.0 & 0.0 & 7.0 & 0.0 & 0.0 & 0.0 & 0.0 & 23.4 \\
\hline
\end{tabular}

\begin{tabular}{|l|l|l|l|l|l|l|l|l|l|l|l|l|l|l|l|}
\hline PV-03d & 0.0 & 50.5 & 8.6 & 0.0 & 0.0 & 41.9 & 23.9 & 0.0 & 4.4 & 0.0 & 0.0 & 0.0 & 0.0 & 21.2 \\
\hline
\end{tabular}

\begin{tabular}{|l|c|c|c|c|c|c|c|c|c|c|c|c|c|c|}
\hline PV-03e & 0.0 & 47.3 & 9.4 & 0.0 & 0.0 & 37.9 & 23.7 & 0.0 & 6.8 & 0.0 & 0.0 & 0.0 & 0.0 & 22.2 \\
\hline PV-03f & 16.3 & 40.6 & 0.0 & 0.0 & 24.6 & & 16.0 & 0.0 & 4.3 & 0.0 & 16.3 & 0.0 & 0.0 & 22.1 \\
\hline
\end{tabular}

Galeria Navarrete

\begin{tabular}{|l|c|c|c|c|c|c|c|c|c|c|c|c|c|c|}
\hline PV-04a & 54.4 & 16.8 & 0.0 & 7.5 & 4.6 & 4.7 & 1.6 & 8.7 & 12.1 & 54.4 & 0.0 & 0.0 & 0.0 & 6.4 \\
\hline PV-04b & 1.8 & 8.0 & 0.0 & 0.0 & 3.6 & 4.4 & 1.6 & 11.2 & 74.1 & 0.0 & 1.8 & 0.0 & 0.0 & 3.3 \\
\hline
\end{tabular}

\begin{tabular}{|l|l|l|l|l|l|l|l|l|l|l|l|l|l|l|}
\hline PV-04c & 2.3 & 12.1 & 0.0 & 0.0 & 6.6 & 5.5 & 0.0 & 14.1 & 66.9 & 0.0 & 2.3 & 0.0 & 0.0 & 4.6 \\
\hline
\end{tabular}

\begin{tabular}{|l|l|l|l|l|l|l|l|l|l|l|l|l|l|l|}
\hline PV-04d & 2.3 & 15.0 & 1.1 & 0.0 & 6.1 & 7.8 & 0.0 & 14.3 & 63.5 & 0.0 & 2.3 & 0.0 & 0.0 & 4.9 \\
\hline
\end{tabular}

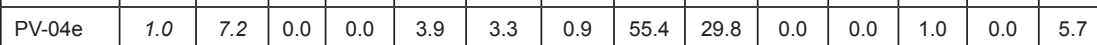

\begin{tabular}{|l|l|l|l|l|l|l|l|l|l|l|l|l|l|l|l|}
\hline PV-05a & 2.4 & 23.8 & 0.0 & 7.9 & 7.5 & 8.4 & 0.0 & 15.7 & 51.6 & 0.0 & 2.4 & 0.0 & 0.0 & 6.5 \\
\hline
\end{tabular}

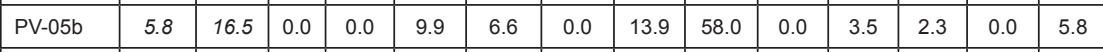

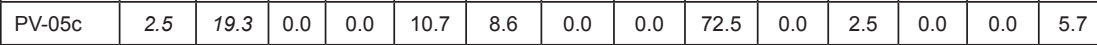

\begin{tabular}{|l|l|l|l|l|l|l|l|l|l|l|l|l|l|l|}
\hline PV-05d & 2.0 & 10.0 & 0.0 & 0.0 & 4.7 & 5.3 & 2.1 & 14.6 & 66.7 & 0.0 & 2.0 & 0.0 & 0.0 & 4.6 \\
\hline
\end{tabular}

\begin{tabular}{|l|l|l|l|l|l|l|l|l|l|l|l|l|l|l|}
\hline PV-05e & 2.1 & 13.1 & 0.0 & 0.0 & 6.8 & 6.3 & 0.0 & 11.2 & 68.7 & 0.0 & 2.1 & 0.0 & 0.0 & 4.9 \\
\hline
\end{tabular}

\begin{tabular}{|l|l|l|l|l|l|l|l|l|l|l|l|l|l|l|}
\hline PV-05f & 2.1 & 10.9 & 0.0 & 0.0 & 6.6 & 4.3 & 1.5 & 14.3 & 66.8 & 0.0 & 2.1 & 0.0 & 0.0 & 4.4 \\
\hline
\end{tabular}

Galeria d'en Pau

\begin{tabular}{|l|c|c|c|c|c|c|c|c|c|c|c|c|c|c|}
\hline PV-06 & 12.1 & 25.3 & 0.0 & 0.0 & 0.0 & 25.3 & 14.5 & 0.0 & 20.4 & 0.0 & 0.0 & 12.1 & 0.0 & 27.7 \\
\hline PV-07 & 4.7 & 18.4 & 0.0 & 0.0 & 6.5 & 11.9 & 8.0 & 14.6 & 3.3 & 4.7 & 0.0 & 0.0 & 29.7 & 21.3 \\
\hline PV-08 & 97.0 & 0.0 & 0.0 & 0.0 & 0.0 & 0.0 & 0.0 & 0.0 & 0.0 & 97.0 & 0.0 & 0.0 & 0.0 & 3.0 \\
\hline PV-09 & 96.5 & 0.0 & 0.0 & 0.0 & 0.0 & 0.0 & 0.0 & 0.0 & 0.0 & 82.6 & 0.0 & 13.9 & 0.0 & 3.5 \\
\hline PV-10 & 86.1 & 0.0 & 0.0 & 0.0 & 0.0 & 0.0 & 4.0 & 0.0 & 0.0 & 80.6 & 0.0 & 5.5 & 0.0 & 9.9 \\
\hline PV-11 & 98.1 & 0.0 & 0.0 & 0.0 & 0.0 & 0.0 & 0.0 & 0.0 & 0.0 & 98.1 & 0.0 & 0.0 & 0.0 & 1.9 \\
\hline
\end{tabular}

as a consequence of the sea level controlled fluctuations of the base level.

\section{Sediments in Galeria d'en Pau}

In this part of the cave a sparse detrital sedimentary accumulation can be observed (Fig. 5). Dusky red sands and silts form a thin deposit less than 5 $\mathrm{cm}$ thick in the floor of the passage and small accumulations less than $1 \mathrm{~cm}$ thick in holes and concavities of the walls can be observed. Sand fraction dominates attaining values higher than $60 \%$ and LOI values between 3 and $6 \%$ (Table 2). The mean grain size corresponds to very fine sand, with a silt percentage of $34.60 \%$, being the mean clay content of $3.35 \%$ (Table 5). The mineral content is quite variable. Phylosilicates (mainly kaolinite) represent nearly $22 \%$ and carbonates around 9\%. Quartz and feldspar are also represented with mean values around 10\% as well as goethite. Mn-oxides and other Fe-oxides, as revealed by the elevated Fe-content of the samples (Table 3), may attain nearly 25\% (Table 4).

In general the sediments present in this part of the cave show great similarities with those found in Sector dels Privilegiats.

\section{Consolidated sediments in Galeria d'en Pau}

In the northeastern end of Galeria d'en Pau, a superposition of two different phreatic passages shows a series of consolidated, well cemented, deposits that can be seen on the floor of the upper conduit. Neither reaching more than several decimeters (maximum observed thickness is $50 \mathrm{~cm}$ ), they correspond to a diverse sequence of strata varying both in color and texture. Although they have not been studied in detail, black cemented silts, reddish yellow cemented silty sands or sands and, pale brown cemented sand, are the main facies present. Their sharp stratification stands out, showing the variability of the different layers and the strong planar millimeter scale clearly visible in the sand levels. The mineralogy of those deposits is clearly dominated by carbonates (mainly calcite), which 
Table 5. Grain size (\%) and statistical parameters $(\mu \mathrm{m})$.

\begin{tabular}{|c|c|c|c|c|c|c|c|c|c|c|c|c|c|c|c|c|c|c|c|}
\hline SAMPLE & $\begin{array}{l}\mathrm{VF} \\
\text { gravel }\end{array}$ & $\begin{array}{l}\text { VC } \\
\text { sand }\end{array}$ & $\begin{array}{c}C \\
\text { sand }\end{array}$ & $\begin{array}{c}\mathrm{M} \\
\text { sand }\end{array}$ & $\begin{array}{c}F \\
\text { sand }\end{array}$ & $\begin{array}{l}\text { VF } \\
\text { sand }\end{array}$ & VC silt & C silt & M silt & $\begin{array}{l}F \\
\text { silt }\end{array}$ & $\begin{array}{l}\text { VF } \\
\text { silt }\end{array}$ & $\begin{array}{l}\% \\
\text { silt }\end{array}$ & $\begin{array}{c}\% \\
\text { clay }\end{array}$ & d50 & mean & so & sk & kur & Mode \\
\hline \multicolumn{20}{|c|}{ Galeria del Tragus } \\
\hline $20-22-1$ & 0.0 & 0.0 & 0.0 & 2.7 & 11.6 & 19.6 & 20.3 & 16.4 & 11.0 & 7.7 & 5.8 & 61.2 & 4.9 & 36.43 & 30.21 & 4.16 & -0.23 & 0.99 & 66.30 \\
\hline $20-22-2$ & 0.0 & 0.0 & 0.3 & 3.0 & 8.8 & 19.8 & 21.2 & 14.8 & 10.5 & 8.1 & 6.5 & 61.1 & 7.0 & 35.11 & 26.36 & 4.53 & -0.28 & 0.98 & 59.50 \\
\hline $20-22-3$ & 0.0 & 0.0 & 1.0 & 29.1 & 42.9 & 11.9 & 3.1 & 3.9 & 2.8 & 2.1 & 1.6 & 13.5 & 1.6 & 188.90 & 164.40 & 2.66 & -0.46 & 2.04 & 218.00 \\
\hline $20-22-4$ & 0.0 & 1.2 & 9.9 & 20.2 & 20.7 & 12.9 & 10.1 & 8.5 & 5.8 & 4.1 & 3.3 & 31.8 & 3.3 & 135.20 & 93.81 & 5.26 & -0.37 & 0.99 & 242.90 \\
\hline VL-M115 & 0.0 & 0.0 & 1.5 & 11.3 & 34.8 & 26.8 & 8.7 & 4.4 & 3.3 & 2.6 & 2.1 & 21.1 & 4.5 & 120.00 & 90.61 & 3.68 & -0.47 & 1.92 & 140.30 \\
\hline VL-M117 & 0.0 & 0.0 & 0.0 & 0.0 & 0.7 & 15.1 & 26.7 & 20.2 & 11.6 & 8.0 & 6.1 & 72.6 & 11.6 & 25.30 & 17.28 & 4.44 & -0.44 & 1.08 & 45.80 \\
\hline \multicolumn{20}{|c|}{ Sector dels Privilegiats (underwater) } \\
\hline PV-01b & 0.0 & 0.1 & 5.4 & 11.9 & 17.5 & 22.2 & 17.6 & 10.7 & 5.9 & 3.7 & 2.7 & 40.6 & 2.3 & 78.26 & 71.75 & 4.14 & -0.16 & 1.14 & 91.72 \\
\hline PV-01c & 0.0 & 0.1 & 5.5 & 13.5 & 21.7 & 23.8 & 15.6 & 8.4 & 4.5 & 2.9 & 2.2 & 33.6 & 1.8 & 96.92 & 87.43 & 3.72 & -0.20 & 1.20 & 113.90 \\
\hline PV-01d & 0.0 & 0.0 & 2.4 & 8.7 & 18.4 & 23.8 & 18.6 & 11.4 & 6.5 & 4.2 & 3.2 & 43.9 & 2.8 & 69.34 & 58.73 & 3.96 & -0.24 & 1.16 & 91.72 \\
\hline PV-01e & 0.0 & 1.8 & 5.2 & 8.8 & 14.5 & 17.8 & 14.9 & 11.4 & 8.7 & 6.5 & 5.5 & 47.0 & 4.9 & 57.78 & 46.90 & 5.81 & -0.17 & 1.01 & 91.72 \\
\hline$P V-01 f$ & 0.0 & 1.1 & 8.9 & 12.3 & 13.9 & 14.0 & 10.8 & 9.3 & 8.7 & 7.8 & 7.2 & 43.8 & 6.0 & 63.01 & 48.26 & 7.18 & -0.19 & 0.82 & 113.90 \\
\hline$P V-02 b$ & 0.0 & 0.9 & 7.8 & 15.5 & 18.3 & 18.7 & 14.6 & 9.4 & 5.7 & 3.9 & 2.8 & 36.4 & 2.4 & 95.32 & 83.60 & 4.60 & -0.20 & 1.05 & 113.90 \\
\hline PV-02c & 0.1 & 3.4 & 10.6 & 14.0 & 15.9 & 15.1 & 12.6 & 9.6 & 7.1 & 5.1 & 3.6 & 38.0 & 2.9 & 95.89 & 80.74 & 5.82 & -0.18 & 0.96 & 157.50 \\
\hline PV-02d & 0.0 & 1.3 & 8.4 & 14.2 & 15.2 & 15.1 & 13.1 & 10.3 & 7.9 & 6.2 & 4.6 & 42.1 & 3.7 & 76.52 & 63.16 & 5.89 & -0.19 & 0.91 & 113.90 \\
\hline PV-02e & 0.0 & 0.2 & 6.3 & 13.5 & 15.3 & 15.1 & 12.8 & 10.4 & 8.6 & 7.4 & 5.8 & 45.0 & 4.6 & 63.99 & 50.59 & 6.06 & -0.21 & 0.87 & 126.90 \\
\hline PV-02f & 0.0 & 1.6 & 12.0 & 18.0 & 17.9 & 15.5 & 11.5 & 8.6 & 6.0 & 4.1 & 2.6 & 32.8 & 2.2 & 122.90 & 98.87 & 5.02 & -0.25 & 0.97 & 301.50 \\
\hline PV-03b & 0.0 & 0.4 & 6.3 & 11.8 & 14.5 & 16.9 & 14.9 & 11.0 & 8.2 & 6.7 & 5.3 & 46.1 & 4.0 & 61.83 & 51.74 & 5.67 & -0.17 & 0.95 & 91.72 \\
\hline PV-03c & 0.0 & 0.3 & 6.2 & 14.4 & 18.9 & 18.7 & 14.2 & 9.3 & 6.5 & 4.6 & 3.5 & 38.1 & 3.4 & 86.67 & 70.03 & 4.94 & -0.25 & 1.05 & 126.90 \\
\hline PV-03d & 0.0 & 0.1 & 7.2 & 17.2 & 18.5 & 15.3 & 12.0 & 8.3 & 6.3 & 5.6 & 5.2 & 37.4 & 4.3 & 92.62 & 64.95 & 5.84 & -0.32 & 0.94 & 242.90 \\
\hline PV-03e & 0.0 & 0.5 & 10.3 & 19.5 & 20.0 & 17.6 & 11.7 & 7.1 & 4.8 & 3.4 & 2.7 & 29.7 & 2.4 & 126.00 & 102.70 & 4.60 & -0.28 & 1.09 & 270.60 \\
\hline PV-03f & 0.0 & 0.1 & 6.0 & 15.2 & 20.9 & 19.9 & 13.1 & 8.5 & 5.8 & 4.1 & 3.3 & 34.8 & 3.1 & 97.35 & 76.79 & 4.67 & -0.29 & 1.10 & 126.90 \\
\hline \multicolumn{20}{|c|}{ Galeria Navarrete } \\
\hline$P V-04 b$ & 0.0 & 0.0 & 0.0 & 1.2 & 10.0 & 20.6 & 20.3 & 15.4 & 11.0 & 8.0 & 6.9 & 61.6 & 6.6 & 33.86 & 25.96 & 4.34 & -0.28 & 0.94 & 66.30 \\
\hline PV-04c & 0.0 & 0.0 & 0.7 & 7.1 & 16.7 & 20.6 & 16.2 & 12.0 & 8.8 & 6.7 & 5.9 & 49.6 & 5.3 & 52.04 & 38.66 & 4.87 & -0.29 & 0.96 & 102.20 \\
\hline PV-04d & 0.0 & 0.0 & 0.0 & 2.3 & 13.3 & 23.1 & 20.1 & 14.5 & 9.9 & 6.7 & 5.3 & 56.5 & 4.8 & 43.50 & 33.96 & 4.06 & -0.30 & 1.00 & 82.31 \\
\hline$P V-04 e$ & 0.0 & 0.0 & 1.3 & 8.3 & 13.0 & 16.8 & 16.1 & 12.5 & 9.7 & 8.0 & 7.3 & 53.6 & 7.0 & 40.19 & 31.67 & 5.63 & -0.20 & 0.90 & 73.87 \\
\hline PV-05a & 0.0 & 0.0 & 0.0 & 1.9 & 13.7 & 23.4 & 18.3 & 12.6 & 9.3 & 7.6 & 6.9 & 54.7 & 6.3 & 42.59 & 29.90 & 4.56 & -0.35 & 0.91 & 91.72 \\
\hline$P V-05 b$ & 0.0 & 0.0 & 0.1 & 6.3 & 21.2 & 23.1 & 14.2 & 10.2 & 7.6 & 6.2 & 5.7 & 43.9 & 5.4 & 64.00 & 42.30 & 4.78 & -0.40 & 0.96 & 126.90 \\
\hline PV-05c & 0.0 & 0.0 & 0.2 & 11.3 & 23.8 & 18.0 & 12.8 & 10.1 & 7.6 & 6.0 & 5.2 & 41.7 & 5.0 & 72.62 & 49.55 & 4.99 & -0.38 & 0.92 & 175.50 \\
\hline PV-05d & 0.0 & 0.0 & 0.1 & 7.3 & 20.6 & 18.9 & 13.2 & 10.5 & 8.6 & 7.5 & 6.8 & 46.6 & 6.5 & 54.01 & 36.77 & 5.34 & -0.34 & 0.84 & 141.40 \\
\hline PV-05e & 0.0 & 0.0 & 0.4 & 15.3 & 26.7 & 16.2 & 12.0 & 9.4 & 7.0 & 5.2 & 4.1 & 37.7 & 3.7 & 94.97 & 63.34 & 4.64 & -0.43 & 0.95 & 195.60 \\
\hline PV-05f & 0.0 & 0.0 & 0.3 & 11.0 & 22.0 & 18.1 & 13.9 & 11.1 & 8.4 & 6.2 & 4.8 & 44.4 & 4.2 & 66.36 & 49.22 & 4.77 & -0.32 & 0.91 & 175.50 \\
\hline \multicolumn{20}{|c|}{ Galeria d'en Pau } \\
\hline PV-06 & 0.0 & 0.3 & 3.4 & 14.4 & 24.5 & 21.9 & 12.9 & 7.8 & 5.2 & 3.8 & 3.0 & 32.7 & 2.8 & 101.60 & 78.33 & 4.17 & -0.34 & 1.18 & 141.40 \\
\hline PV-07 & 0.0 & 0.1 & 6.8 & 15.4 & 18.9 & 18.4 & 11.6 & 8.1 & 6.5 & 5.5 & 4.8 & 36.5 & 3.9 & 92.02 & 66.06 & 5.52 & -0.31 & 0.99 & 126.90 \\
\hline
\end{tabular}

represent more than $90 \%$ (Table 4). The percentage of Fe-oxides is also significant (Table 3).

Although in this part of the cave these consolidated sediments are more clearly visible, they also exist in other passages (i.e., Galeria del Tragus; Fig. 6).

The consolidated deposits are probably related with an earlier phreatic phase in the cave evolution where the grains detached from the cave walls due to the contrasting corrosion of the bioclastic calcarenites, produced an abundant source of carbonate sand that was later accumulated thanks to the currents through the widened passages. This autochthonous sedimentation alternated sporadically with external flooding episodes.

\section{Sediments in Galeria del Tragus}

The sediments found in Galeria del Tragus represent the most important accumulation existing in all the galleries and chambers of the cave. In an irregular outcrop cut by several collapses (Fig. 7) and extending

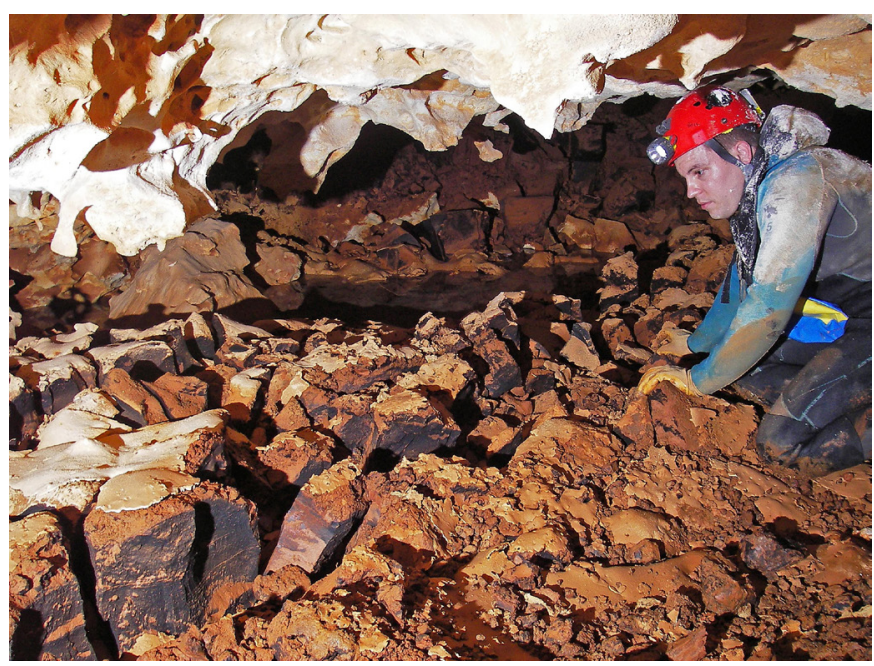

Fig. 4. Silty sediments accumulated at Galeria Navarrete not far from the current water table. A Fe-Mn patina can be observed (photo: Antoni Merino). 


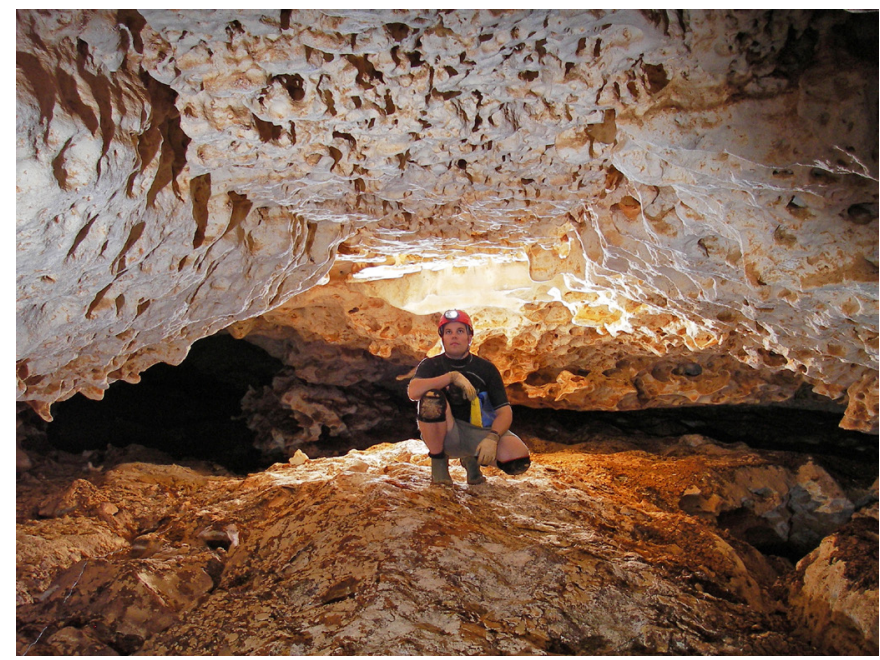

Fig. 5. Muddy accumulation of red sediments at Galeria d'en Pau, partially covered by a calcite crust (photo: Antoni Merino).

along more than $200 \mathrm{~m}$ of passage, the deposits with a mean thickness of $2.5 \mathrm{~m}$ form a simple sedimentary sequence that displays small lateral variations and reveal four clearly differentiated levels (Fornós et al., 2010). It corresponds to a predominantly sand accumulation at the base and a clayey silt deposition becoming dominant at the top (Table 2). The entire sequence is partially covered by a thin flowstone. Mineralogical composition of sediments is characterized by the presence of carbonate minerals and of silicic materials (quartz and feldspars) together with minerals from the clay (Table 4).

From bottom to top (Fig. 8), the lower level (UNIT - A) composed by reddish-brown sandstone shows a thickness of 1-1.5 $\mathrm{m}$ having a high degree of cementation. The basal contact with the rock is not observable because it is below the water table. This level is quite homogeneous without showing any sedimentary structures and, apparently, without paleontological remains.

The next level (UNIT - B) is very similar, but with remarkable differences in the cementation degree along the stratigraphic column. This level is formed by carbonated brown fine sands and has a thickness of $25-30 \mathrm{~cm}$ without clear lamination. A slight stratification can be observed, mainly due to differences in the grain size (average at the base

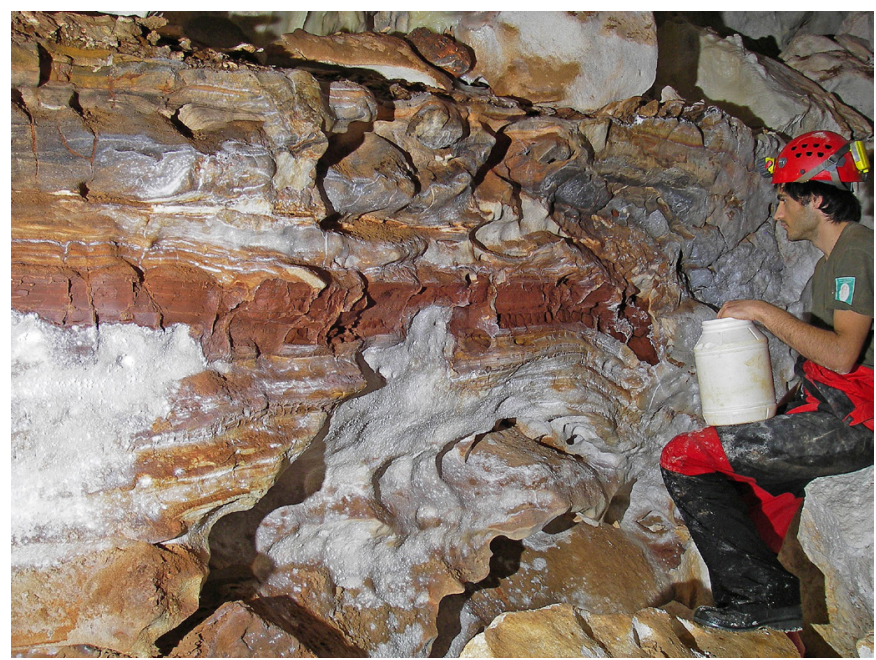

Fig. 6. Well-stratified and consolidated sediments at Galeria del Tragus (photo: Antoni Merino).

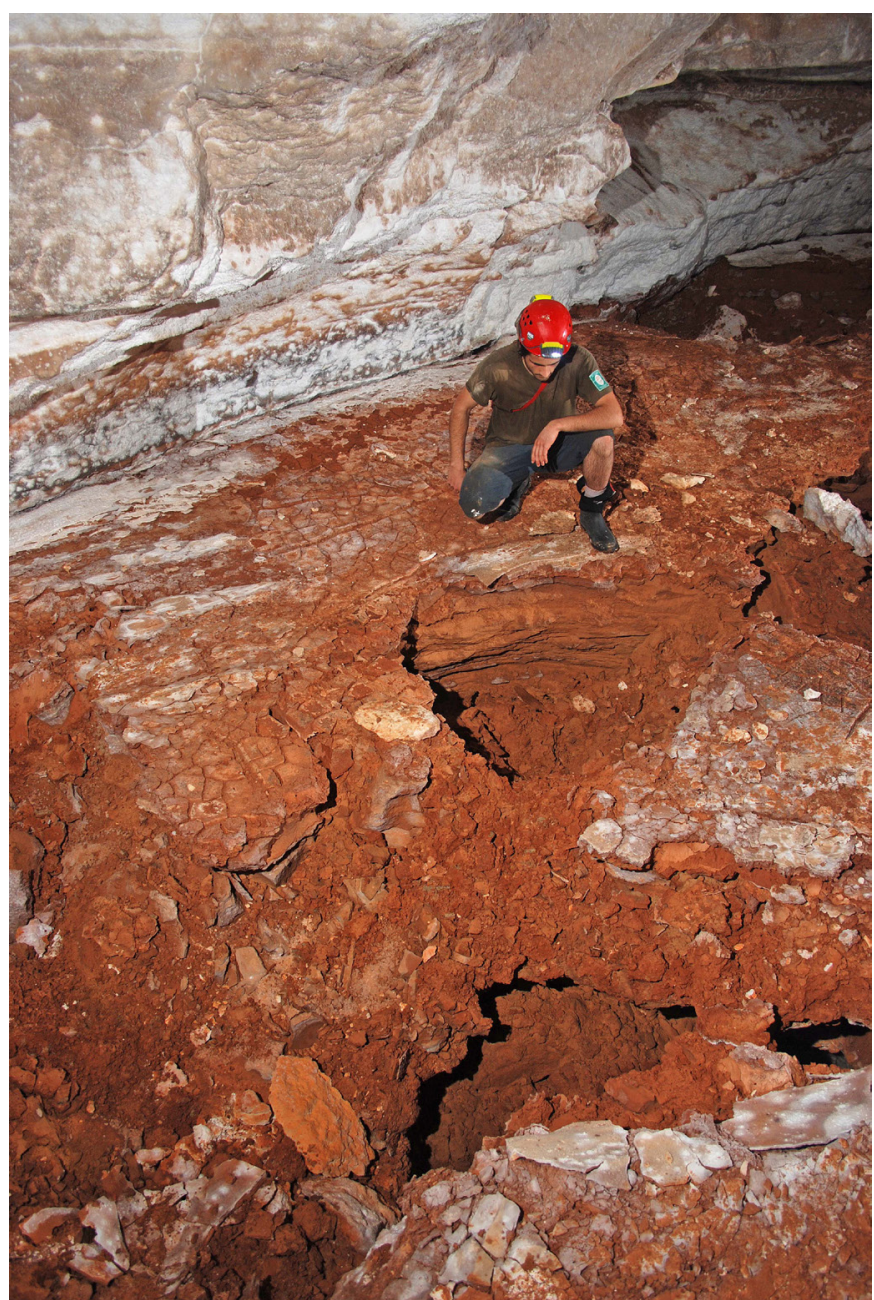

Fig. 7. Galeria del Tragus sediment accumulation with important paleontological remains (Bover et al., 2014). Some collapses are also visible (photo: Antoni Merino)

$179.6 \mu \mathrm{m}$ and average at the top $139.80 \mu \mathrm{m})$, and showing a very good sorting (Table 5). Interspersed in the basal part of this level and related to layers with a coarser texture, a mixed facies characterized by a low degree of sorting can be observed. It is sandy silt with a high proportion of clay.

The sequence continues with a very small and discontinuous subaerial flowstone level (UNIT - C) which leads to a very clear sediment unit formed by a facies of brown silts and clays $1-2 \mathrm{~cm}$ in thickness, showing a clean contact at the base.

The sequence that fills up the final part of the Galeria del Tragus ends with a coarser facies (UNIT - D). It consists of reddish sandy silt, with interspersed levels of a low sorting degree formed by silt $(60 \%)$, clay $(>20 \%)$ and fine and very fine sand (near 20\%), and other layers with a good sorting and formed mainly by silt (> 70\%). This facies also contains sporadically heterometric and angular fragments of limestone, of gravel (or greater) size, from the gravitational collapse of the walls. This unit contains the main part of the vertebrate fossil remains found in all the sequence. The most superficial part displays a slight subaerial flowstone layer, which also covers part of the osteological remains found on the surface.

Texture and carbonate composition (bioclastic) characteristics of the sands (UNITS-A and B), 


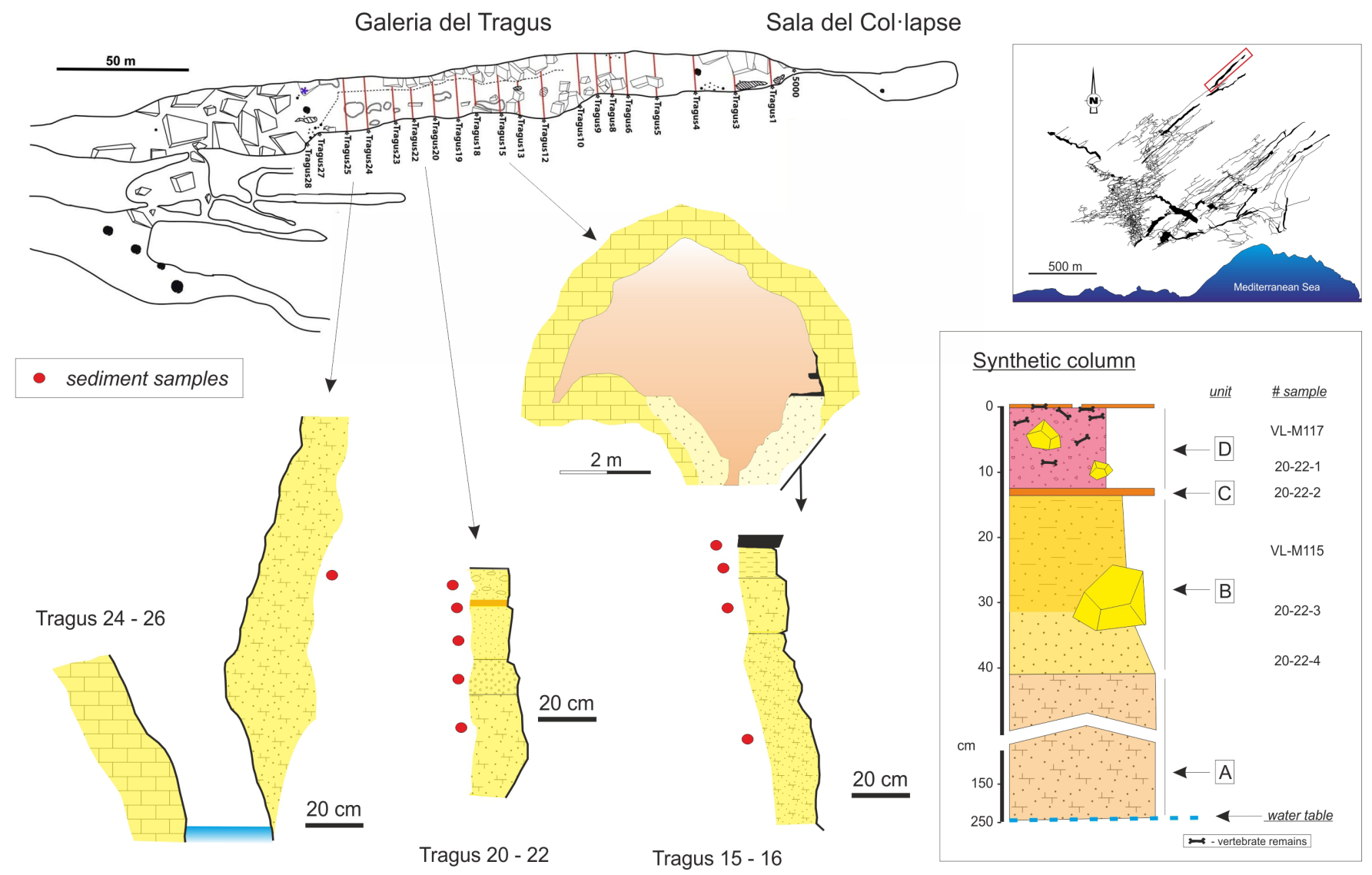

Fig. 8. Topographic survey and sections of Galeria del Tragus with the representation of sampled levels and synthetic stratigraphic column (Fornós et al., 2010; Bover et al., 2014). See location on Fig. 1 (topographic survey courtesy of the Federació Balear d'Espeleologia).

together with their mean grain size and sorting, suggest an eolian origin of sediments being deposited through a nearby ancient entrance. The lack of tractive structures suggests a deposition promoted by low dynamic runoff processes. The presence in the basal levels of mixed facies seems to indicate that mobilization and mixing of eolian sands with muddy materials related to external detrital inputs by surface runoff from outside infiltration occurred. The UNIT-C is interpreted as the partial flooding of the cavity with subsequent decantation of the material transported in suspension. The red sandy silt facies (UNIT-D) can be interpreted as infiltration deposits provided by surface runoff during periods of heavy rainfall.

\section{Other deposits}

Apart from the detrital sediments described above, other kind of deposits occur in some of the cave chambers. Breakdown facies including unsorted boulders and cobbles (ranging in size from centimeters to several meters) with subangular textures are located as big accumulations on the floor of most of the greatest chambers. They show a chaotic disposition with no signs of any imbricated structure or transport. Their distribution is clearly related with the textural characteristics of the host rock (reef front facies, Ginés et al., 2014) and corresponds to the accumulation of debris from roof collapse favored by the preferential dissolution of aragonitic corals that build this part of the host rock cave.

\section{DISCUSSION: DIFFERENTIATING DEPOSITIONAL ENVIRONMENTS}

Sediments in coastal karst represent an information source, nowadays poorly understood, of climate and past sea-levels. The environments within the coastal karst caves are continuously changing from vadose to phreatic conditions in response to repeatedly flooding and draining caused by oscillating past Quaternary sea levels. Different subenvironments that can be described by their sedimentary content are then changing continuously (van Hengstum et al., 2011).

In the case of Cova des Pas de Vallgornera, the interaction of three main speleogenetic pathways (meteoric recharge, coastal mixing, and hypogene deepseated recharge; Ginés et al., 2014) that had accounted along the Quaternary sea level history, configures a really complex morpho-sedimentary setting.

Presence of fine detrital deposits representing the autochthonous sedimentation is very scarce in the whole cave system of Cova des Pas de Vallgornera, both in the air-filled and underwater passages. Only in the innermost galleries of the cave, patchy accumulations few centimeters in thickness can be observed, except in Galeria Navarrete and surrounding area where a considerable amount of muddy red deposits are present. In general, this detrital sedimentation is quite similar to other coastal caves of Mallorca (Fornós et al., 2009b) where muddy sediments derived from the infiltration of soil materials are deposited; in those cases the presence of carbonate rock particles detached from the walls is very scarce. 
The periodical flooding of the cave by meteoric waters provoked the accumulation of very thin laminated fine sediments. In general, the observed sequence shows a slight diminution of the grain size from the base to the top indicating a faint decrease in the hydrodynamic energy conditions of the cave with time.

The preferential distribution of these reddish sediments occurs mainly in secondary passages like at Galeria Navarrete. Probably, main episodes of meteoric recharge derived from runoff related to some sinks from a major surface ravine (as that existing close to the northeastern end of the cave) drive water to the main drainage conduits. The higher flow that probably held in these master conduits prevented the sediments accumulation, and only when ponded waters occurred in their derivation to secondary conduits and minor lateral galleries, the waters became decelerated having time to settle out the carried suspended load. Presence of mud cracks on top of the sequence indicates the restoration of vadose conditions. Nevertheless we can't discharge to consider these sediments as backswamp or quietwater facies (Bosch \& White, 2004; Springer et al., 1997). Being deposited during one of the periodic episodes of permanent flooding of the cave during the Quaternary, they can suffer posterior washing (both siliciclastic thin sediments or detrital carbonates characteristics of the water mixing dissolution environments) in the main conduits due to a substantially higher flow in vadose conditions.

On the other hand, the already referred sedimentary sequence of Galeria del Tragus is completely different (Fornós et al., 2010). It is formed by sands (Fig. 9) and muddy silts that host highly interesting fossil osteological vertebrate (mainly mammals) remains linked to the existence of an ancient entrance to the cave system (Bover et al., 2014), thus permitting to consider the sediment sequence as allochthonous (entrance facies). The characteristics of these sediments seem to indicate the presence of a cave mouth through which these sand deposits first and then the sediments of surface runoff entered the cave until the likely closing of it after the collapse of this ancient entrance. The absence of a clear lamination and flow structures, in these sand deposits of clear eolian origin, suggests a ramp-type deposition favored by gravity. The whole stratigraphic set with a subhorizontal location of the deposits suggests a low dynamic aquatic environment. The extension (some hundred meters) along the gallery, points toward episodes of surface recharge presumably linked to sinks from major outside creeks (Ginés et al., 2014). The presence of articulated skeletons of the bovid Myotragus agrees with the hypothesis of an original open entrance close to the deposit, and seems to indicate a limited horizontal transport of the bones inside the cave.

The sediments sequence at Galeria del Tragus points to the importance of the meteoric recharge in the evolution of the passages forming the inner sectors of the cave. An evident change in the external environmental conditions, from an arid and probably cold period (prevalence of sands with eolian origin)
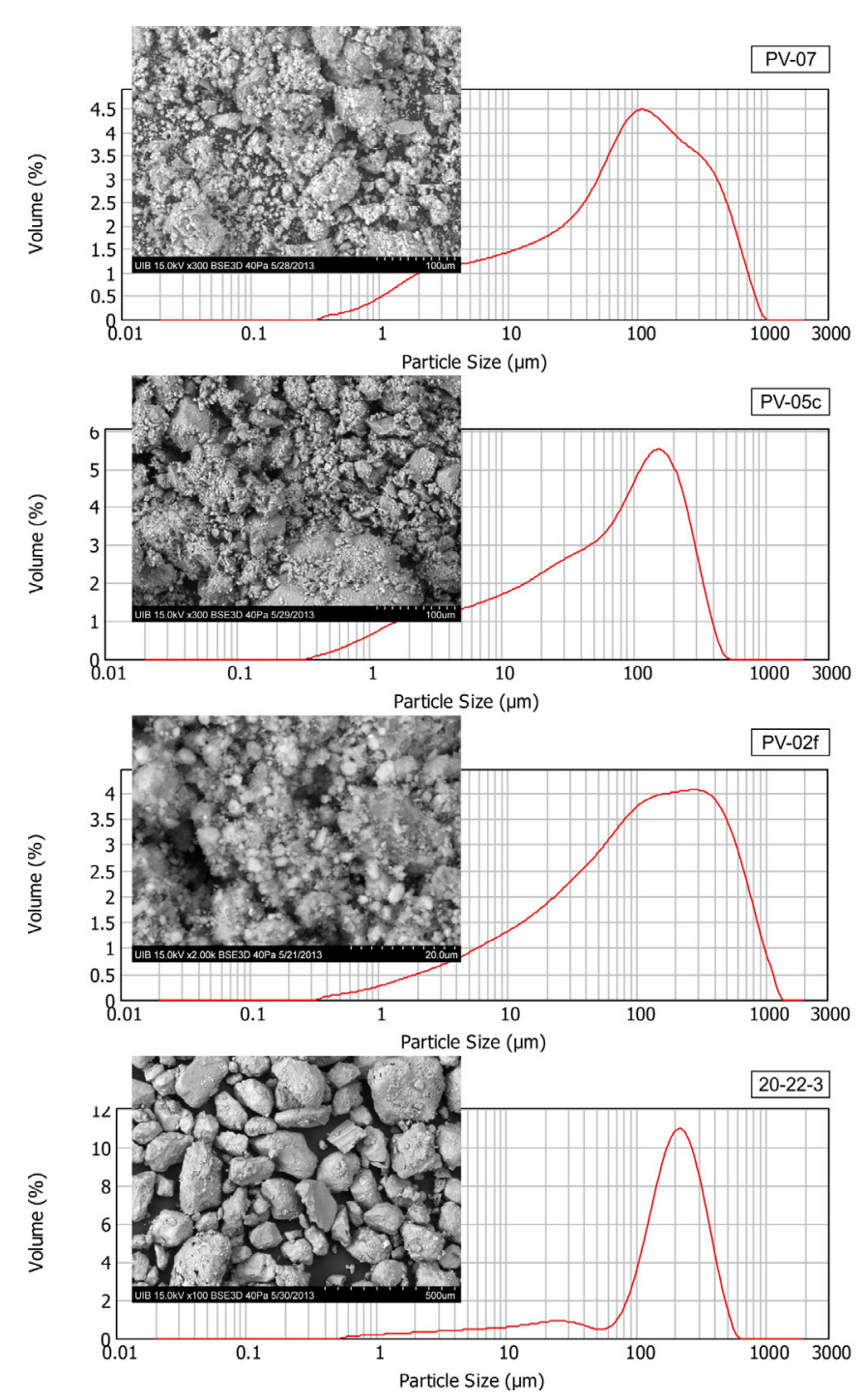

Fig. 9. Representative SEM images and particle size distribution of selected samples from sediments in Cova des Pas de Vallgornera. Sample numbers refers to Table 2 .

to a more humid and probably warm one, can be inferred from the stratigraphic sequence. During the humid period the increasing of rainfall would favor the entry of finer allochthonous material through surface runoff. In any case, the simplicity and homogeneity of the stratigraphic sequence indicate a deposition during a short period of time.

The presence of paleontological remains in these detrital sediments sheds light on the age of the deposits as well as to the reconstruction of the speleogenetic evolution of the cave (Ginés et al., 2014). They contain, among other remains of terrestrial mammals (Bover et al., 2014), articulated skeletons and skulls of a bovid (Myotragus) that arrived to the island during the Late Miocene and evolved isolated since then. The archaic intermediate forms placed between Myotragus antiquus and Myotragus kopperi, brings an Early Pleistocene age for this paleontological deposit (Bover et al., 2014).

The aforementioned siliciclastic fine sedimentation shares the spotlight with the accumulation of goethiterich sediments and amorphous manganese oxides. Present patchily in several degrees through the entire cave passages and chambers (as Galeria d'en Pau), but especially evident in the nowadays submerged 
conduits (Sector dels Privilegiats), $\mathrm{Mn}$ and Fe-rich sediments are a common fact. Ferromanganese deposits in caves are widely documented in the scientific literature (Northup et al., 2003; Spilde et al., 2006; White et al., 2009; Gázquez et al., 2011, among others). Several origins have been reported for the iron and manganese oxides amorphous material. Among them, the organic activity has been invoked (Hill \& Forti, 1997) or the leaching of manganese from residual material below bat guano, or from the soil under reducing conditions (Fairchild \& Baker, 2012), or the supply of Fe and Mn by low-temperature hydrothermal fluids (Aquilina et al., 2014). The black coatings are also common in ponded flood waters deposited from highly oxidized waters carrying Mn ions from the solution of impure limestone (Ford $\&$ Williams, 2007). In the case of Cova des Pas de Vallgornera, as discussed before, the host rock is extremely pure and the presence of guano deposits is null; in addition, the characteristics of the "terra rosa" soil with a poor vegetal cover present outside the cave does not seem to favor the export on $\mathrm{Fe}^{2+}$ and $\mathrm{Mn}^{2+}$ ions. On the other hand, the abundant presence of morphologies of hypogenic origin (Ginés et al., 2009a; Merino et al., 2011) throughout the cave seems to relate these deposits to low temperature hydrothermal processes that may have taken place in different phases during the cave evolution (Ginés et al., 2014). This has also been highlighted by the precipitation of uncommon minerals as post drainage deposits related to vents in the floor of several passages (Fornós et al., 2011; Ginés et al., 2014; Onac et al., 2014).

Presence of $\mathrm{Mn}-\mathrm{Fe}$ crusts on top of the Galeria Navarrete fine sediments can also indicate and abrupt environmental change in the cave (Gázquez et al., 2011).

Apart from the breakdown facies, which relate to the main chambers that develop in accordance to the reef front facies distribution within the hosting Miocene rock, the rest of detrital sediment accumulation occurs at joint guided phreatic passages hosted in more calcisiltitic lagoon facies. The scarce sediment accumulation in the main passages would indicate periods of intense meteoric recharge that would have washed the accumulated sediments in the floor of passages being only deposited as odd accumulations on secondary passages or other restricted zones as hollows in walls, or blind conduits.

Remnants of carbonate consolidated sediments, which are eroded and fossilized by mainly siliciclastic unconsolidated sediments, show a clear difference in texture and composition. They correspond to different processes that characterize different events. Moreover, the link with entrance facies during periods of external aperture of the cave as well as the presence of carbonate crusts on top of most deposits also indicate the succession of periods of flooding with others of air-filled evolution.

As a whole, sediments in Cova des Pas de Vallgornera reflect the complexity of processes and sedimentary facies involved in this exceptional coastal cave (Fig. 10). The different morpho-sedimentary environments that can be distinguished within the cave can help to decode its evolutionary history (Ginés et al., 2014), mainly related to the sea-level fluctuations during the Plio-Quaternary times.

\section{CONCLUSIONS}

Although different kinds of sediments have been described with very similar characteristics to other coastal caves previously reported in Mallorca (Fornós et al, 2009b), at the present day sedimentary processes in Cova des Pas de Vallgornera are irrelevant. The most surprising fact and the main difference with other coastal caves in the island is the scarce presence of sediments in its chambers, and passages. Water chemistry influenced by the coastal mixing processes controls most of

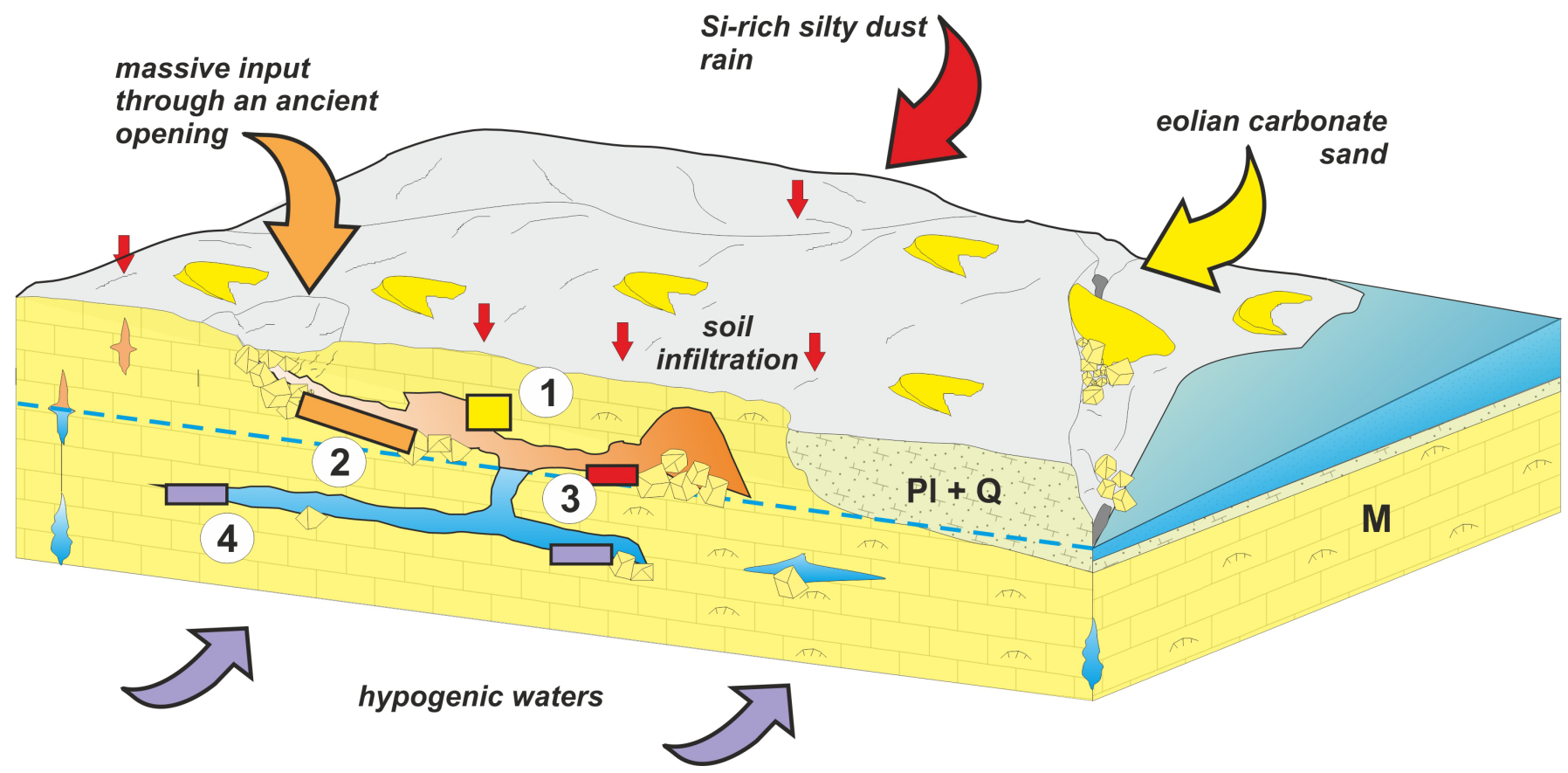

Fig. 10. Illustrative sketch representing the main sedimentary environments and processes involved in Cova des Pas de Vallgornera. 1) Consolidated carbonate deposits from Galeria d'en Pau; 2) Allochthonous deposits in Galeria del Tragus with vertebrate fossil remains; 3) Si-rich muddy deposits from Galeria Navarrete; 4) Mixed muddy deposits rich in Mn and Fe. M - Miocene; PI + Q - Pliocene and Pleistocene calcarenites. 
the autochthonous sedimentation related to the corrosion of walls; periodical meteoric flooding of the passages transported into the cave fine sediments from the external sources (mainly soil); depending on the characteristics of the ancient openings of the cave, allochthonous littoral sandy sediments, were accumulated at some spots as entrance facies. Along with these processes, the activity of the hypogenic episodes that acted at some moments during the cave evolution (Ginés et al., 2009a; Merino et al., 2011) masked part of the sediments present in the cave and added uncommon mineralogies (Merino et al., 2009; Onac et al., 2014).

In terms of the geochronological evolution, the osteological remains from Galeria del Tragus have been attributed to the Early Pleistocene (Fornós et al., 2010; Bover et al., 2014), so dating back the formation of the passages to the Pliocene. The observed consolidated sediments that are fossilized by these detrital paleontological deposits must have been accumulated probably along the Late Pliocene. This fact constrains the genesis of the main passages to mid-Pliocene times, where some high sea levels occurred (Dwyer \& Chandler, 2009), or even earlier. The evolutionary history of the cave has experimented the successive periods of sea level changes during the Quaternary times, probably forming some additional cave horizons (Ginés et al., 2014) where different sedimentary processes can occur, probably redistributing part of the sediment but with no meaningful sedimentary addition due to the obstruction of the external apertures.

Trying to correlate speleogenetic pathways and sedimentary processes, several different situations can be identified, that could originate however transitional or mixed environments. The meteoric recharge is linked with the detrital sedimentation, including siliciclastic fines and coarse surface materials (basically eolian sands or other materials entered through ancient cave entrances). On the other hand, coastal mixing dissolution is responsible for the autochthonous sedimentation basically by means of the release of carbonate particles from the calcarenitic cave walls, though this situation can cause as well the dissolution of an important part of the particulate material. Finally, the hypogenic deep-seated recharge is probably responsible for the $\mathrm{Fe}$ - and $\mathrm{Mn}$-rich waters that can be oxidized when approaching the water table. The long lasting episodes of low sea-level during the Quaternary, have allowed the formation of desiccation cracks and the deposition of flowstone layers, even in nowadays underwater passages. Unfortunately, the extremely fluctuating sea-controlled base level makes quite difficult the detailed chronological reconstruction of the cave morphogenesis.

\section{ACKNOWLEDGMENTS}

The authors would like to thank Drs. Ferran Hierro and Joan Cifre (Serveis Cientificotècnics, Universitat de les Illes Balears in Palma) for their support while conducting the mineral analyses, as well as Guillem Mulet, Miquel A. Perelló and Miquel A. Vives for the underwater sampling. Funding from Spanish MINECO (MICINN) - FEDER project CGL2010-18616 is acknowledged. Thanks are debt to Federació Balear d'Espeleologia and the Departament de Cultura i Patrimoni del Consell de Mallorca as well as to the Direcció General de Biodiversitat del Govern de les Illes Balears by bringing help and the corresponding legal permissions. We also thank the anonymous reviewers for offering constructive criticism that greatly improved this manuscript.

\section{REFERENCES}

Aquilina A., Homoky W.B., Hawkes J.A., Lyons T.W. \& Mills, R.A. 2014 - Hydrothermal sediments are a source of water column Fe and Mn in the Bransfield Strait, Antarctica. Geochimica et Cosmochimica Acta.

http://dx.doi.org/10.1016/j.gca.2014.04.003

Blott S.J. \& Pye K., 2001 - A grain size distribution and statistics package for the analysis of unconsolidated sediments. Earth Surface Processes and Landforms, 26 (11): 1237-1248.

http://dx.doi.org/10.1002/esp.261

Bosch R.F. \& White W.B., 2004 - Lithofacies and transport of clastic sediments in karstic aquifers. In: Sasowsky I.D. \& Mylroie J. (Eds.), Studies of cave sediments. Physical and chemical records of paleoclimate. Kluwer Academic/Plenum Publishers, New York, 1-22. http:/ / dx.doi.org/10.1007/978-1-4419-9118-8_1

Bover P., Valenzuela A., Guerra C., Rofes J., Alcover J.A., Ginés J., Fornós J.J., Cuenca-Bescós G. \& Merino A., 2014 - The Cova des Pas de Vallgornera (Llucmajor, Mallorca): a singular deposit containing an extraordinarily well preserved Early Pleistocene vertebrate fauna. International Journal of Speleology, 43 (2): 175-192.

http://dx.doi.org/10.5038/1827-806X.43.2.6

Butzer K.W. \& Cuerda J., 1962 - Coastal stratigraphy of southern Mallorca and its implications for Pleistocene chronology of the Mediterranean Sea. Journal of Geology, 70: 389-416. http://dx.doi.org/10.1086/626833

Downs R.T. \& Hall-Wallace M., 2003 - The American mineralogist crystal structure database. American Mineralogist, 88: 247-250.

Dwyer G.S. \& Chandler M.A., 2009 - Mid-Pliocene sea level and continental ice volume based on coupled benthic $\mathrm{Mg} /$ Ca palaeotemperatures and oxygen isotopes. Philosophical Transactions of the Royal Society A, 367: 157-168. http://dx.doi.org/10.1098/rsta.2008.0222

Egozcue J.J., 1971 - Estudio del cono de materiales alóctonos de la Cova de sa Font. Speleon, 18: 49-53.

Farrant A.R. \& Smart P.L., 2011 - Role of sediment in speleogenesis; sedimentation and paragenesis. Geomorphology, 134: 79-93. http://dx.doi.org/10.1016/j.geomorph.2011.06.006

Fiol L.A., Fornós J.J., Gelabert B. \& Guijarro J.A., 2005 - Dust rains in Mallorca (Western Mediterranean): Their occurrence and role in some recent geological processes. Catena, 63: 64-84. http://dx.doi.org/10.1016/j.catena.2005.06.012

Folk R.L. \& Ward, W.C., 1957 - Brazos River bar: a study in the significance of grain size parameters. Journal of Sedimentary Petrology, 27: 3-26.

http:/ / dx.doi.org/10.1306/74D70646-2B21-11D7$\underline{8648000102 \mathrm{C} 1865 \mathrm{D}}$ 
Fornós J.J., Gelabert B., Ginés A., Ginés J., Tuccimei P. \& Vesica P., 2002 - Phreatic overgrowths on speleothems: a useful tool in structural geology in littoral karstic landscapes. The example of eastern Mallorca (Balearic Islands). Geodinamica Acta, 15: 113-125. http://dx.doi.org/10.1016/S0985-3111(02)01083-5

Fornós J.J., Clemmensen L.B., Gómez-Pujol L. \& Murray A.S., 2009a - Late Pleistocene carbonate aeolianites on Mallorca, Western Mediterranean: a luminescence chronology. Quaternary Science Reviews, 28: 2697-2709. http://dx.doi.org/10.1016/j.quascirev.2009.06.008

Fornós J.J., Ginés J. \&. Gràcia F., 2009b - Present-day sedimentary facies in the coastal karst caves of Mallorca island (western Mediterranean). Journal of Cave and Karst Studies, 71 (1): 86-99.

Fornós J.J., Ginés J., Merino A. \& Bover P., 2010 - El rebliment sedimentari de la galeria del Tragus a la cova des Pas de Vallgornera (Llucmajor, Mallorca). Bolletí de la Societat d'Història Natural de les Balears, 53: 179-192.

Fornós J.J., Merino A., Ginés J., Ginés A. \& Gràcia F., 2011 - Solutional features and cave deposits related to hypogene speleogenetic processes in a littoral cave of Mallorca Island (western Mediterranean). Carbonates and Evaporites, 26 (1): 69-81. http://dx.doi.org/10.1007/s13146-010-0040-3

Fornós J.J., Pomar L. \& Ramos-Guerrero E., 2002 - Balearic Islands. In: Gibbons W. \& Moreno T. (Eds.), The Geology of Spain. London: The Geological Society: 327-334.

Gabriel J.J., Reinhardt E.G., Peros M.C., Davidson D.E., van Hengstum P.J. \& Beddows P., 2009 Palaeoenvironmental evolution of Cenote Aktun Ha (Carwash) on the Yucatan Peninsula, Mexico and its response to Holocene sea-level rise. Journal of Paleolimnology, 42: 199-213.

http://dx.doi.org/10.1007/s10933-008-9271-x

Gázquez F., Calaforra J.M. \& Forti P., 2011 - Black MnFe crusts as markers of abrupt palaeoenvironmental changes in El Soplao Cave (Cantabria, Spain). International Journal of Speleology, 40 (2): 163-169. http://dx.doi.org/10.5038/1827-806X.40.2.8

Gelabert B., Sàbat F. \& Rodríguez-Perea, A., 1992 - A structural outline of the Serra de Tramuntana of Mallorca (Balearic Islands). Tectonophysics, 203: 167-183. http://dx.doi.org/10.1016/0040-1951(92)90222-R

Ginés A. \& Ginés J., 1974 - Consideraciones sobre los mecanismos de fosilización de la Cova de sa Bassa Blanca y su paralelismo con formaciones marinas del Cuaternario. Bolletí de la Societat d'Història Natural de les Balears, 19: 11-28.

Ginés A. \& Ginés J., 2007 - Eogenetic karst, glacioeustatic cave pools and anchialine environments on Mallorca Island: a discussion of coastal speleogenesis. International Journal of Speleology, 36 (2): 57-67. http://dx.doi.org/10.5038/1827-806X.36.2.1

Ginés A., Ginés J., Gómez-Pujol L., Onac B.P. \& Fornós J.J. (Eds.), 2012 - Mallorca: a Mediterranean Benchmark for Quaternary Studies. Monografies de la Societat d'Història Natural de les Balears, 18. Palma de Mallorca, 219 p.

Ginés J. \& Ginés A., 2011 - Classificació morfogenètica de les cavitats càrstiques de les Illes Balears. Endins, 35 / Monografies de la Societat d'Història Natural de les Balears, 17: 85-102.

Ginés J., Fornós J.J., Ginés A., Merino A. \& Gràcia F., 2014 - Geologic constraints and speleogenesis of Cova des Pas de Vallgornera, a complex coastal cave from Mallorca Island (Western Mediterranean). International Journal of Speleology, 43 (2): 105-124.

http://dx.doi.org/10.5038/1827-806X.43.2.2
Ginés J., Fornós J.J., Trias M., Ginés A. \& Santandreu G., 2007 - Els fenòmens endocàrstics de la zona de Ca n'Olesa: la Cova de s'Ónix $i$ altres cavitats veïnes (Manacor, Mallorca). Endins, 31: 5-30.

Ginés J., Ginés A., Fornós J.J., Merino A. \& Gràcia F., 2009a - On the role of hypogene speleogenesis in shaping the coastal endokarst of southern Mallorca (Western Mediterranean). In: Klimchouk A.B. \& Ford D.C. (Eds.), Hypogene speleogenesis and karst hydrogeology of artesian basins. Ukrainian Institute of Speleology and Karstology, Simferopol. Special Paper, 1: 91-99.

Ginés J., Ginés A., Fornós J.J., Merino A. \& Gràcia F., 2009b - About the genesis of an exceptional coastal cave from Mallorca Island (Western Mediterranean). The lithological control over the pattern and morphology of Cova des Pas de Vallgornera. In: White W.B. (Ed.), Proceedings of the $15^{\text {th }}$ International Congress of Speleology. Kerrville: National Speleological Society, 1: 481-487.

Gómez-Pujol L., Gelabert B., Fornós J.J., Pardo-Pascual J.E., Rosselló V.M., Segura F.S. \& Onac B.P., 2013 - Structural control on the presence and character of calas: Observations from Balearic Islands limestone rock coast macroforms. Geomorphology, 194: 1-15. http://dx.doi.org/10.1016/j.geomorph.2013.03.012

Gràcia F., Clamor B., Fornós J.J., Jaume D. \& Febrer M., 2006 - El sistema Pirata - Pont - Piqueta (Manacor, Mallorca): geomorfologia, espeleogènesi, hidrologia, sedimentologia i fauna. Endins, 29: 25-64.

Gràcia F., Clamor B., Jaume D., Fornós J.J., Uriz M.J., Martín D., Gil J., Gracia P., Febrer M. \& Pons, G.X., 2005 - La Cova des Coll (Felanitx, Mallorca): espeleogènesi, geomorfologia, hidrologia, sedimentologia, fauna $i$ conservació. Endins, 27: 141-186.

Gràcia F., Fornós J.J., Clamor B., Febrer M. \& Gamundí, P., 2007 - La Cova de sa Gleda I. Sector Clàssic, Sector de Ponent i Sector Cinc-Cents (Manacor, Mallorca): geomorfologia, espeleogènesi, sedimentologia $i$ hidrologia. Endins, 31: 43-96.

Gràcia F., Fornós J.J., Gamundí P., Clamor B., Pocoví J. \& Perelló M.A., 2009a - Les descobertes subaquàtiques a la Cova des Pas de Vallgornera (Llucmajor, Mallorca): història $i$ descripció dels descobriments, hidrologia, espeleotemes, sediments, paleontologia i fauna. Endins, 33: $35-72$.

Gràcia F., Jaume D., Ramis D., Fornós J.J., Bover P., Clamor B., Gual M.A. \& Vadell, M., 2003 - Les coves de Cala Anguila (Manacor, Mallorca). II: La Cova Genovesa o Cova d'en Bessó. Espeleogènesi, geomorfologia, hidrologia, sedimentologia, fauna, paleontologia, arqueologia i conservació. Endins, 25: 43-86.

Hearty P.J., Olson S.L., Kaufman D.S., Edwards R.L. \& Cheng H., 2004 - Stratigraphy and geochronology of pitfall accumulations in caves and fissures, Bermuda. Quaternary Science Reviews, 23: 1151-1171. http://dx.doi.org/10.1016/j.quascirev.2003.09.008

Iacovello F. \& Martini I., 2012 - Provenance and geological significance of red mud and other clastic sediments of the Mugano Cave (Montagnola Senese, Italy). International Journal of Speleology, 41 (2): 317-328.

http://dx.doi.org/10.5038/1827-806X.41.2.17

Kovacs S.E., van Hengstum P.J., Reinhardt E.G., Donnelly J.P. \& Albury N.A., 2013 - Late Holocene sedimentation and hydrologic development in a shallow coastal sinkhole on Great Abaco Island, The Bahamas. Quaternary International, 317: 118-132.

http://dx.doi.org/10.1016/j.quaint.2013.09.032

Klimchouk A.B., 2009 - Morphogenesis of hypogenic caves. Geomorphology, 106: 100-117.

http://dx.doi.org/10.1016/j.geomorph.2008.09.013 
Krajcarz M.T., Bosák P., Šlechta S., Pruner P., Komar M., Dresler J. \& Madeyska T., 2013 - Sediments of Biśnic Cave (Poland): Lithology and stratigraphy of the Middle Paleolithic site. Quaternary International, 326-327: 6-19. http://dx.doi.org/10.1016/j.quaint.2013.10.017

López J.M. \& Mateos R.M., 2006 - Control estructural de las anomalias geotérmicas y la intrusión marina en la plataforma de Llucmajor y la cubeta de Campos (Mallorca). Las aguas subterráneas en los países mediterráneos. Instituto Geológico y Minero de España, Madrid. Serie Hidrogeología y Aguas Subterráneas, 17: 607-613.

Martini I., 2011 - Cave clastic sediments and implications for speleogenesis: New insights from the Mugnano Cave (Montagnola Senese, Northern Apennines, Italy). Geomorphology, 134: 452-460.

http://dx.doi.org/10.1016/j.geomorph.2011.07.024

Merino A., Fornós, J.J. \& Onac, B.P., 2009 - Preliminary data on mineralogical aspects of cave rims and vents in Cova des Pas de Vallgornera, Mallorca. In: White, W.B. (Ed.), Proceedings of the $15^{\text {th }}$ International Congress of Speleology. Kerrville: National Speleological Society, 1: 307-311.

Merino A., Ginés J. \& Fornós J.J., 2011a - Evidències morfològiques de processos hipogènics a cavitats de Mallorca. In: Gràcia F., Ginés J., Pons G.X., Ginard A. \& Vicens D. (Eds.), El carst: patrimoni natural de les Illes Balears. Endins, 35 / Monografies de la Societat d'Història Natural de les Balears, 17: 165-182.

Merino A., Mulet A., Mulet G., Croix A., Kristofersson A., Gràcia F. \& Perelló M.A., 2014a - Cova des Pas de Vallgornera (Mallorca, Spain): history of exploration and cave description. International Journal of Speleology, 43 (2): 95-104. http://dx.doi.org/10.5038/1827-806X.43.2.1

Merino A., Ginés J., Tuccimei P., Soligo M. \& Fornós J.J., 2014b - Speleothems in Cova des Pas de Vallgornera: their distribution and characteristics within an extensive coastal cave from the eogenetic karst of southern Mallorca (Western Mediterranean). International Journal of Speleology, 43 (2): 125-143.

http://dx.doi.org/10.5038/1827-806X.43.2.3

Muhs D.R., Budahn J., Avila A., Skipp G., Freeman J. \& Patterson D., 2010 - The role of African dust in the formation of Quaternary soils on Mallorca, Spain and implications for the genesis of red Mediterranean soils. Quaternary Science Reviews, 29: 2518-2543.

http://dx.doi.org/10.1016/j.quascirev.2010.04.013

Northup D.E., Barns S.M., Yu L.E., Spilde M.N., Schelble R.T., Dano K.E., Crossey L.J., Connolly C.A., Boston P.J., Natvig D.O. \& Dahm C.N., 2003 - Diverse microbial communities inhabiting ferromanganese deposits in Lechuguilla and Spider caves. Enviromental Microbiology, 5 (11): 1071-1086.

http://dx.doi.org/10.1046/j.1462-2920.2003.00500.x

Onac B.P., Fornós J.J., Merino A., Ginés J. \& Diehl J., 2014 - Linking mineral deposits to speleogenetic processes in Cova des Pas de Vallgornera (Mallorca, Spain). International Journal of Speleology, 43 (2): 143157. http://dx.doi.org/10.5038/1827-806X.43.2.4

Polk J.S., van Beynen P., Asmeron Y. \& Polyak V.J., 2013 Reconstructing past climate using carbon isotopes from fulvic acids in cave sediments. Chemical Geology, 360-361: 1-9. http://dx.doi.org/10.1016/j.chemgeo.2013.09.022

Polk J.S., van Beynen P. \& Reeder P.P., 2007 - Late Holocene environmental reconstruction using cave sediments from Belize. Quaternary Research, 68: 5363. http://dx.doi.org/10.1016/j.yqres.2007.03.002

Pomar L., 1991 - Reef geometries, erosion surfaces and high-frequency sea-level changes, Upper Miocene Reef Complex, Mallorca, Spain. Sedimentology, 38: 243-269. http://dx.doi.org/10.1111/j.1365-3091.1991.tb01259.x
Pomar L., Ward W.C. \& Green D.G., 1996 - Upper Miocene reef complex of the Llucmajor area, Mallorca, Spain. In: Franseen E., Esteban M., Ward W.C. \& Rouchy J.M. (Eds.), Models for carbonate stratigraphy from Miocene reef complexes of the Mediterranean regions. SEPM Concepts in Sedimentology and Paleontology, 5: 191-225.

Reams M.W., 1968 - Cave sediments and the geomorphic history of the Ozarks (PhD Thesis): St Louis, Mo., Washington University, $167 \mathrm{p}$.

Sàbat F., Gelabert B., Rodríguez-Perea A. \& Giménez J., 2011 - Geological structure and evolution of Majorca: Implications for the origin of the Western Mediterranean. Tectonophysics, 510: 217-238. http://dx.doi.org/10.1016/j.tecto.2011.07.005

Sasowsky I.D. \& Mylroie J., 2004 - Studies of cave sediments. Physical and chemical records of paleoclimate. Kluwer Academic/Plenum Publishers, New York, 329 p. http://dx.doi.org/10.1007/978-1-4419-9118-8

Schulte E.E. \& Hopkins B.G., 1996 - Estimation of soil organic matter by weight loss-on- ignition. In: F.R. Magdoff, M.A. Tabatabai, \& E.A. Hanlon, Jr. (Eds.), Soil organic matter: analysis and interpretation. Madison, WI.: Soil Science Society of America: 21-31.

SpildeM.N., NorthupD.E. \&Boston P.J., 2006-Ferromanganese deposits in the caves of the Guadalupe Mountains. New Mexico Geological Society Guidebook, $57^{\text {th }}$ Field Conference, Cave and Karst in Southern Mexico, 161-166.

Springer G.S., Kite J.S. \& Schmidt V.A., 2014 - Cave sedimentation, genesis, and erosional history in the Cheat River Canyon, West Virginia. Geological Society of America Bulletin, 109(5): 524-532.

http://dx.doi.org/10.1130/00167606(1997)109<0524:CSGAEH>2.3.CO;2

Sroubek P., Diehl J.F. \& Kadlec J., 2007 - Historical climate record from flood sediments deposited in the interior of Spirálka Cave, Czech Republic. Palaeogeography, Palaeoclimatology, Palaeoecology, 251: 547-562. http://dx.doi.org/10.1016/j.palaeo.2007.05.001

Thomas M.L.H., Eakins K.E. \& Logan A., 1991 - Physical characteristics of the anchialine ponds of Bermuda. Bulletin of Marine Science, 48 (1): 125-136.

Tuccimei P., Ginés J., Delitala M.C., Ginés A., Gràcia F., Fornós, J.J. \& Taddeucci, A., 2006 - Last interglacial sea level changes in Mallorca Island (western Mediterranean). High precision $U$-series data from phreatic overgrowths on speleothems. Zeitschrift für Geomorphologie, 50 (1): 1-21.

van Hengstum P.J., Reinhardt E.G., Beddows P.A. \& Gabriel J.J., 2010 - Linkages between Holocene paleoclimate and paleohydrogeology preserved in a Yucatan underwater cave. Quaternary Science Reviews, 29: 2788-2798. http://dx.doi.org/10.1016/j.quascirev.2010.06.034

van Hengstum P.J. \& Scott D.B., 2012 - Sea-level and coastal circulation controlled Holocene groundwater development in Bermuda and caused a meteoric lens to collapse 1600 years ago. Marine Micropaleontology, 90-91: 29-43. http://dx.doi.org/10.1016/j.marmicro.2012.02.007

van Hengstum P.J., Scott D.B., Gröcke, D.R. \& Charette M.A. 2011 - Sea level controls sedimentation and environments in coastal caves and sinkholes. Marine Geology, 286: 35-50. http://dx.doi.org/10.1016/j.margeo.2011.05.004

van Hengstum P.J., Scott D.B. \& Javaux E.J., 2009 Foraminifera in elevated Bermudian caves provide further evidence for $+21 \mathrm{~m}$ eustatic sea level during Marine Isotope Stage 11. Quaternary Science Reviews, 28: 1850-1860. http://dx.doi.org/10.1016/j.quascirev.2009.05.017

White W.B., 2007 - Cave sediments and paleoclimate. Journal of Caves and Karst Studies, 69 (1): 76-93.

White W.B., Vito C. \& Scheetz B.E., 2007 - The mineralogy and trace element chemistry of black manganese oxide deposits from caves. Journal of Cave and Karst Studies, $\mathbf{7 1}$ (2): 136-143. 